\title{
Overview of areal changes of the ice shelves on the Antarctic Peninsula over the past 50 years
}

\author{
A. J. Cook and D. G. Vaughan \\ British Antarctic Survey, Cambridge, UK \\ Received: 5 August 2009 - Published in The Cryosphere Discuss.: 14 August 2009 \\ Revised: 18 December 2009 - Accepted: 12 January 2010 - Published: 2 February 2010
}

\begin{abstract}
In recent decades, seven out of twelve ice shelves around the Antarctic Peninsula (AP) have either retreated significantly or have been almost entirely lost. At least some of these retreats have been shown to be unusual within the context of the Holocene and have been widely attributed to recent atmospheric and oceanic changes. To date, measurements of the area of ice shelves on the AP have either been approximated, or calculated for individual shelves over dissimilar time intervals. Here we present a new dataset containing up-to-date and consistent area calculations for each of the twelve ice shelves on the AP over the past five decades. The results reveal an overall reduction in total ice-shelf area by over $28000 \mathrm{~km}^{2}$ since the beginning of the period. Individual ice shelves show different rates of retreat, ranging from slow but progressive retreat to abrupt collapse. We discuss the pertinent features of each ice shelf and also broad spatial and temporal patterns in the timing and rate of retreat. We believe that an understanding of this diversity and what it implies about the underlying dynamics and control will provide the best foundation for developing a reliable predictive skill for ice-shelf change.
\end{abstract}

\section{Introduction}

The changing position of the margin of the Antarctic ice sheet, both floating and grounded, is currently being mapped as part of the USGS Coastal-change and Glaciological Maps of Antarctica programme (Williams and Ferrigno, 1998). As part of this programme, a comprehensive time-series of icefront changes around the Antarctic Peninsula was compiled from sources dating from 1940 to 2002 (Cook et al., 2005). The time-series further reveal changes in glacier, ice shelf

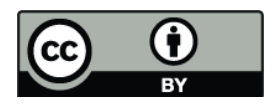

Correspondence to: A. J. Cook (acook@bas.ac.uk) and other ice fronts and is published as hardcopy maps with detailed accompanying reports (Ferrigno et al., 2006; Ferrigno et al., 2008) and digital data (Scientific Committee on Antarctic Research, 2005). The main trends observed in the fronts of marine and tidewater glaciers of the Antarctic Peninsula have already been discussed elsewhere (Cook et al., 2005), but the changes in ice shelf fronts were excluded from that study and are brought up to date and described here.

The retreat of ice shelves on the Antarctic Peninsula over the past century has been widely documented and attributed to atmospheric warming (e.g., Vaughan and Doake, 1996; Doake and Vaughan, 1991a; Mercer, 1978; Rott et al., 1998; Skvarca et al., 1999) and several specific mechanisms have been suggested to explain particular phases of retreat and collapse (Scambos et al., 2000; Doake et al., 1998; MacAyeal et al., 2003; Vieli et al., 2006). The role of atmospheric warming as the primary driver of ice-shelf retreat is not, however, a view that is universally accepted, with some evidence that ice-shelf thinning may, in part, be the result of oceanographic change which may "pre-condition" ice shelves to retreat (Shepherd et al., 2003). Thus the question remains as to whether future ice-shelf change, not just around the Antarctic Peninsula, will be dominated by oceanographic or atmospheric drivers of change.

Greater clarity has, however, been achieved with regard to another important question regarding ice-shelf retreat. It has now been demonstrated quite clearly, that the loss of floating ice shelves and ice in fjords can cause profound acceleration and thinning of the tributary glaciers flowing from the Antarctic Peninsula plateau (Rignot et al., 2004, 2005; Rott et al., 2002; Scambos et al., 2003; Pritchard and Vaughan, 2007; De Angelis and Skvarca, 2003; Hulbe et al., 2008; Pritchard et al., 2009). Although rates of acceleration will probably not persist indefinitely, it implies, and will almost certainly continue to imply, a contribution to sea-level rise. Although the effects of ice-shelf retreat on the tributary glaciers will not be extensively discussed in this paper, this is

Published by Copernicus Publications on behalf of the European Geosciences Union. 
Table 1. Summary of area changes found in published material for ten ice shelves located on the Antarctic Peninsula. The figures were obtained from references that recorded area changes of a particular ice shelf between the earliest and most recent dates available. There is other published material not listed here that gives areas of ice shelves on specific dates (e.g. Reynolds, 1988; Rott et al., 1998); calculations of ice loss (e.g. Braun et al., 2009) or area calculations based on different methods (Suyetova, 1986).

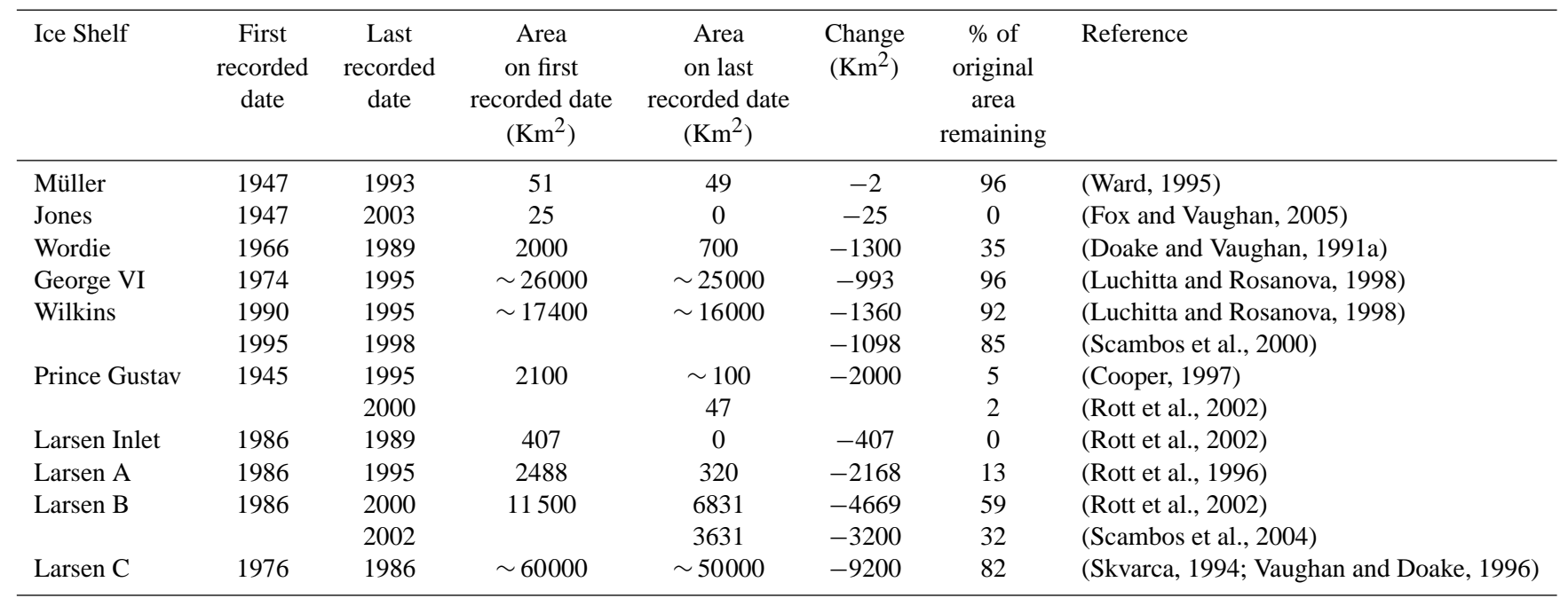

an important underlying reason for attempting to understand the processes that cause ice-shelf retreat, which is the subject of the current study.

Individual ice shelves have been monitored and documented elsewhere (Table 1; see Fig. 1a for locations), but until now there has been no consistent approach to measuring changes for all the ice shelves on a regular time-series. We present a discussion of ice-shelf areas measured based on the USGS coastal-change dataset, which has been updated for this study using Envisat ASAR images from 2008/9 (acquired for the IPY Polar View programme ${ }^{1}$ ). These data have been collected using a consistent methodology to give reliable areas of each ice shelf over the past five decades. We present an analysis of the changes and discuss the trends observed.

\section{Method}

The methods used in compiling the coastal-change database are described in detail elsewhere (Cook et al., 2005). In summary, historical data sources, including early maps, aerial photographs and satellite images, were used to map ice fronts onto a common reference, using ArcGIS. The quantity of source material available varied considerably across the AP. In some regions, photography coverage and satellite images allowed more than one coastline position to be mapped within each decade, whilst in other regions there was little or no coverage in some decades, and this implied large gaps between recorded positions. The quality of the source material

\footnotetext{
${ }^{1}$ http://www.polarview.org/
}

also varied, so for this reason, each coastline digitised was assigned a reliability rating (Ferrigno et al., 2006). For the purpose of measuring how the ice shelves have changed in area over the last 50 years, one ice front position was chosen for each decade. This coastline was chosen according to the following scheme:

- As close to mid-decade as possible.

- Where this was not possible, a coastline at either the start or end of the decade, depending on which has the most complete, reliable ice front or most representative line.

- Where there was no coastline available within the decade, a coastline at the end of the previous decade as an approximate position.

- Where none of the above information was available, the decade remained blank.

It should be noted that the coastline chosen could have occurred prior to or following a major ice-shelf collapse event and it has not been selected specifically to reflect these events.

The resulting areas therefore represent the area of the ice shelf on a particular year, and do not represent an average position for the decade. Accuracies cannot be assigned to each area value as the variation within each decade is not quantifiable using our data. The reliability rating attached to each coastline indicates the likely errors in the positioning of the ice front and should be taken into account when assessing the accuracy of the areas (Table 2). Since $87 \%$ of all coastlines 

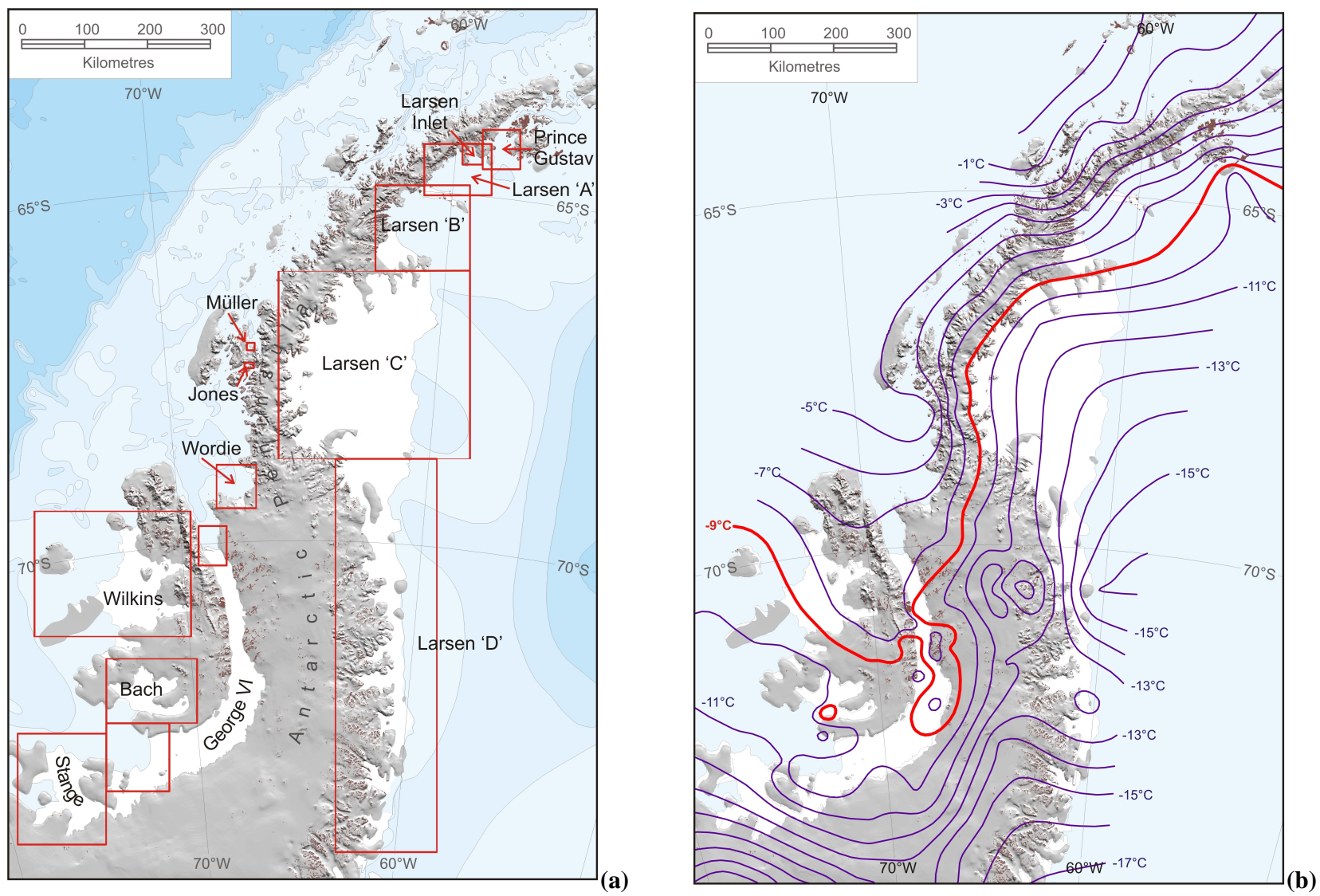

Fig. 1. (a) Location of ice shelves on the Antarctic Peninsula (b) Contours of interpolated mean annual temperature in 2000 A.D., as compiled by Morris and Vaughan (2003).

are reliable to within $150 \mathrm{~m}$, and because area accuracies depend not only on variations in the width but also the length of the coastline, the areas are rounded to $1 \mathrm{~km}^{2}$ precision.

Using ArcGIS, the coastlines were joined to the grounding lines describing each ice shelf (obtained from the Antarctic Digital Database SCAR, 2005) to create a single polygon for each ice shelf, in each decade. The area of each polygon was then measured, using a Lambert Azimuthal Equal-Area projection.

\section{Results}

On the AP, the total area of ice shelf lost (from the earliest available records to the present) is $28117 \mathrm{~km}^{2}$ (Table 3). This is a total of $18 \%$ of the original area of floating ice (where the "original area" is based on the earliest available areas for each ice shelf). Despite the episodic nature of the retreat of individual ice shelves, on the decadal timescale there has been a steady decline in total area of the Antarctic Peninsula ice shelves that began in the 1970s and continued to the present (Fig. 2).

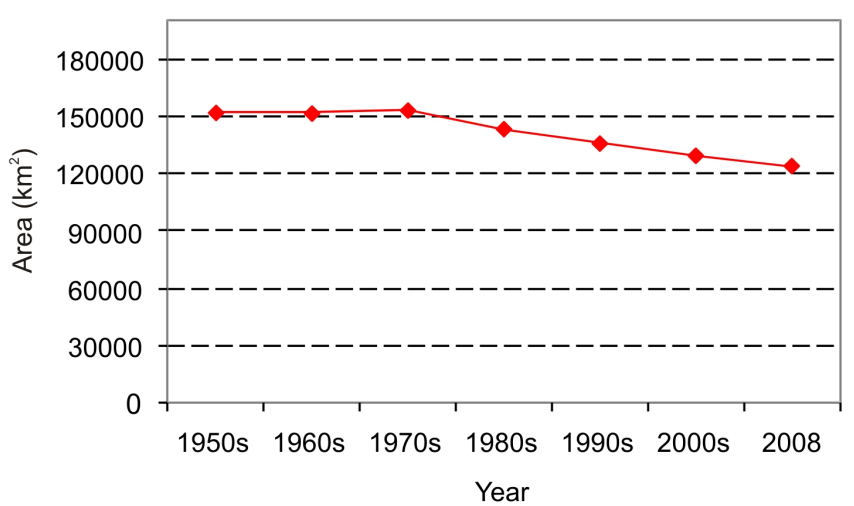

Fig. 2. Total area of floating ice on the Antarctic Peninsula over the past 5 decades.

The largest change in ice lost from all ice shelves combined, occurred between the 1970s and 1980s (from $1621 \mathrm{~km}^{2}$ ice gain in the previous decade, to $9823 \mathrm{~km}^{2}$ ice loss), with a slight decline in ice loss since the 1980s from $7640 \mathrm{~km}^{2}$ to $5461 \mathrm{~km}^{2}$ lost within the present decade (Fig. 3). 
Table 2. Coastlines used to compile ice shelf fronts came from different source material. These are from specific years and have different reliability ratings, as defined below (reliability shown in brackets). See Ferrigno et al. (2006) for a description of the source material contributing to each reliability rating.

\begin{tabular}{lccccccc}
\hline Ice shelf & $1950 \mathrm{~s}$ & $1960 \mathrm{~s}$ & $1970 \mathrm{~s}$ & $1980 \mathrm{~s}$ & $1990 \mathrm{~s}$ & $2000 \mathrm{~s}$ & $2008 / 9$ \\
\hline Müller & $1957(1)$ & $1969(1)$ & $1974(1)$ & $1986(1)$ & $1996(1)$ & $2001(1)$ & $2008(1)$ \\
Jones & $1957(1)$ & $1969(1)$ & $1978(1)$ & $1986(1)$ & $1996(1)$ & $2001(1)$ & $2008(1)$ \\
Wordie & $1947(2)$ & $1966(2)$ & $1974(2)$ & $1989(1)$ & $1997(1)$ & $2001(1)$ & $2008(1)$ \\
Wilkins & $1947(4)$ & & & $1990(1)$ & $1997(3)$ & $2001(1)$ & $2008 / 9(1)$ \\
George VI (N) & $1947(1)$ & $1966(3)$ & $1974(3)$ & $1989(1)$ & $1997(2)$ & $2001(1)$ & $2008(1)$ \\
George VI (S) & $1947(3)$ & $1968(2)$ & $1973(2)$ & $1986(1)$ & $1997(2)$ & & $2008(1)$ \\
Bach & $1947(3)$ & $1968(3)$ & $1973(2)$ & $1986(1)$ & $1997(2)$ & $2001(1)$ & $2008(1)$ \\
Stange & & & $1973(2)$ & $1986(1)$ & $1997(2)$ & $2001(1)$ & $2008(1)$ \\
Prince Gustav (N) & $1957(1)$ & $1957(1)$ & $1977(3)$ & $1988(1)$ & $1993(2)$ & $1997(2)$ & $2008(1)$ \\
Prince Gustav (S) & $1957(5)$ & $1961(3)$ & $1961(3)$ & $1989(2)$ & $1993(2)$ & $1997(2)$ & $2008(2)$ \\
Larsen A & $1961(3)$ & $1963(1)$ & $1975(2)$ & $1986(1)$ & $1995(2)$ & $2000(1)$ & $2008(1)$ \\
Larsen B & & $1963(1)$ & $1975(2)$ & $1986(1)$ & $1999(2)$ & $2002(1)$ & $2008(1)$ \\
Larsen C & & $1963(2)$ & $1975(2)$ & $1988(1)$ & $1997(2)$ & $2001(2)$ & $2008(1)$ \\
Larsen D & & $1966(2)$ & & $1988(1)$ & $1997(2)$ & $2000(1)$ & $2008 / 9(1)$ \\
\hline
\end{tabular}

\begin{tabular}{ll}
\hline Reliability ratings & \\
\hline Rely 1 & Within $60 \mathrm{~m}$ \\
Rely 2 & Within $150 \mathrm{~m}$ \\
Rely 3 & Within $300 \mathrm{~m}$ \\
Rely 4 & Within 600m \\
Rely 5 & Within 1 km \\
\hline
\end{tabular}

Vaughan and Doake (1996) suggested that an ice shelf that is no longer viable is one that will suffer progressive retreat, perhaps over a period of many years, with no major readvance. Of the twelve ice shelves, three have shown significant retreat (Larsen B, Müller and Wilkins) and four of them have shown total disintegration (Jones, Wordie, Prince Gustav, Larsen A) within the last half-century (Table 2). The definition of significant retreat we use here is where less than $70 \%$ of the original ice shelf area remains; total disintegration is where $10 \%$ or less of the original area remains.

Five of the ice shelves (George VI, Bach, Stange, Larsen C and Larsen D) have more than $90 \%$ of their original area remaining and are showing no steady retreat. Larsen D is the only ice shelf to have shown overall advance over this time period. The largest ice shelf, Larsen C, is still the largest contributor to the overall remaining ice-shelf area, and is currently at approximately $90 \%$ of its original area and shows no significant areal change.

It has been proposed that the thermal limit of viability for ice shelves on the AP is north of the $-9{ }^{\circ} \mathrm{C}$ isotherm (Vaughan and Doake, 1996; Morris and Vaughan, 2003) and our results largely corroborate this theory as all five unchanging ice shelves lie south of the $-9^{\circ} \mathrm{C}$ isotherm (in 2000)

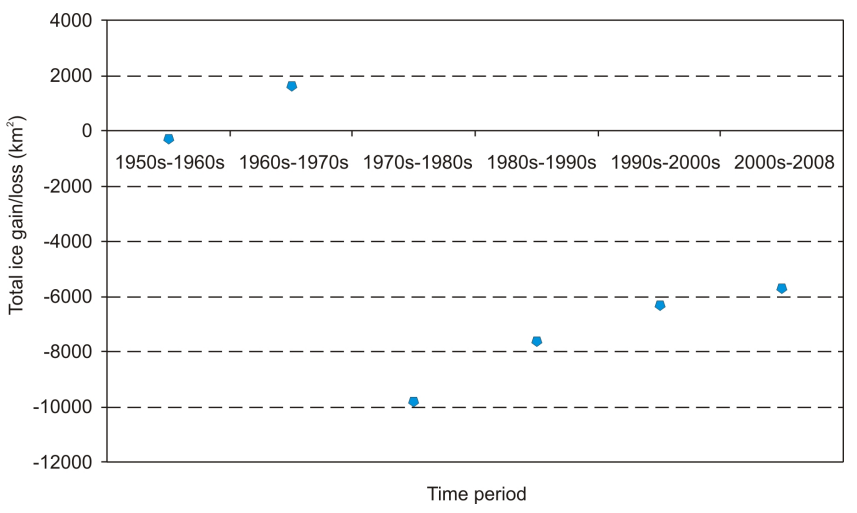

Fig. 3. Total amount of floating ice lost between each decade

(see Fig. 1b). As the following descriptions indicate, the ice shelves that have retreated have generally followed a pattern that suggests a southerly migration of a climatic limit. The Wilkins Ice Shelf is the latest and southernmost ice shelf to begin collapse, suggesting that the thermal boundary has continued to move southwards and may soon threaten the currently stable ice shelves on the southwest AP.

\section{Description of change on individual ice shelves}

Despite the overall trend of retreat of ice shelves around the AP, individual ice shelves have shown considerable differences in the timing and course of their retreat. Our expectation is that these variations result from the particular characteristics of both the local forcing experienced by individual ice shelves and their internal dynamics and specifics of their mass balance. Indeed, the ice shelves of the AP are diverse 
Table 3. Changes in area of ice shelves on the Antarctic Peninsula. The total loss for each ice shelf is calculated from the earliest recorded area to the most recently measured area in 2008/9. The \% of ice remaining is also based on the earliest recorded areas. N. B. The decade "2000s" consists of ice front positions between 2000-2002, with the latest position "2008/9" given separately.

\begin{tabular}{lrrrrrrrrr}
\hline Ice shelf & $1950 \mathrm{~s}$ & $1960 \mathrm{~s}$ & $\begin{array}{c}1970 \mathrm{~s} \\
\text { Areas in km }\end{array}$ & $1980 \mathrm{~s}$ & $1990 \mathrm{~s}$ & $2000 \mathrm{~s}$ & $2008 / 9$ & $\begin{array}{r}\text { Total } \\
\text { change }\left(\mathrm{km}^{2}\right)\end{array}$ & $\begin{array}{c}\% \\
\text { remaining }\end{array}$ \\
\hline Müller & 78 & 69 & 60 & 64 & 45 & 44 & 40 & -38 & 51 \\
Jones & 29 & 31 & 36 & 26 & 21 & 10 & 0 & -29 & 0 \\
Wordie & 1420 & 1917 & 1538 & 827 & 906 & 312 & 139 & -1281 & 10 \\
Wilkins & 16577 & & & 15986 & 14694 & 13663 & 11144 & -5434 & 67 \\
George VI & 25984 & 25806 & 25249 & 24707 & 24260 & & 24045 & -1939 & 93 \\
Bach & 4798 & 4721 & 4825 & 4685 & 4582 & 4562 & 4487 & -311 & 94 \\
Stange & & & 8286 & 8148 & 8030 & 7949 & 8022 & -264 & 97 \\
Prince Gustav & 1632 & 1299 & 1328 & 1019 & 665 & 276 & 11 & -1621 & 1 \\
Larsen A & 4021 & 3736 & 3873 & 3394 & 926 & 638 & 397 & -3624 & 10 \\
Larsen B & & 11573 & 11958 & 12190 & 8299 & 4429 & 2407 & -9166 & 21 \\
Larsen C & & 56131 & 58036 & 50241 & 51246 & 51593 & 50837 & -5295 & 91 \\
Larsen D & & 21716 & & 22372 & 22345 & 21851 & 22602 & 886 & 104 \\
& & & & & & & & \\
Total Area & 152246 & 151862 & 153483 & 143661 & 136020 & 129589 & 124128 & & \\
Total Change & & -384 & 1621 & -9823 & -7640 & -6432 & -5461 & -28117 & 82 \\
\hline
\end{tabular}

and have many distinct individual characteristics. It is also clear that changes such as thinning, increases in tributary flow and rheological weakening must be considered alongside ice front retreat if we are to correctly interpret the type of collapse shown by individual ice shelves.

So while the changes seen in each ice shelf may be broadly interpreted through discussion of these factors, as is undertaken below, it is clear that a formal sensitivity analysis using models that can take account of differences in mass balance sensitivity and ice rheology, similar to those performed for Larsen B (Vieli et al., 2007), are the most powerful tool available in understanding the detailed aspects of the course of change. Similarly, the "structural glaciology" approach based on a detailed examination of individual retreat events (Glasser and Scambos, 2008; Braun and Humbert, 2009) can provide greater insight into particular retreat events than can be presented here.

The description of each ice shelf that follows provides a discussion of the changes in areas measured for this study, and an overview of published research that has discussed processes important during retreat. It should be noted that the areas calculated here may differ from those that appeared in earlier studies (i.e. those listed in Table 1) for several reasons: interpretations of grounding line positions may differ, as may the images from which the ice front positions were measured; the methods and accuracy of digitising is not consistent between studies and neither is the approach to whether internal ice rises and rumples should be included in the area of the ice shelf. The map projection on which the areas were calculated can also make a significant difference.

\subsection{West coast of the Antarctic Peninsula, north to south}

\subsubsection{Müller Ice Shelf (Fig. 4.1)}

Müller Ice Shelf $\left(67^{\circ} 14^{\prime} \mathrm{S}\right.$ and $\left.66^{\circ} 52^{\prime} \mathrm{W}\right)$ is one of the smallest remaining ice shelves, currently covering $40 \mathrm{~km}^{2}$. It is the northernmost ice shelf on the western side of the AP and drains an area of the Arrowsmith Peninsula. Two glaciers feed the ice shelf (Bruckner and Antevs), which is pinned on Humphreys Island. Aerial photography from 1947 revealed a significant advance beyond the island until 1956 (Ward, 1995), after which retreat began and by 1963 it was almost back to its 1947 position. A second period of ice front advance of $4 \mathrm{~km}^{2}$ took place between 1974 and 1986. This was followed by retreat until 1996, after which it has been relatively stable. It is currently at approximately $50 \%$ of its size in 1957, although a lack of ground surveying makes interpretation of the grounding line difficult.

A longer historic context for Müller Ice Shelf, obtained from marine sediment cores, shows that advance took place ca. 400 years ago (Domack et al., 1995). Although this correlates with the onset of the Little Ice Age (LIA), climatic conditions across Antarctica were variable and this period was one of warmer temperatures along the AP. Domack et al. (1995) concluded that the advance at this time was probably linked to colder circumpolar deep water (CDW) filling the fjord than at present. The warm CDW that is currently within the fjord may be contributing to the rapid undermelt of the ice-shelf system observed in recent years. However, with $50 \%$ of the ice shelf remaining and little change in area 
Müller Ice Shelf

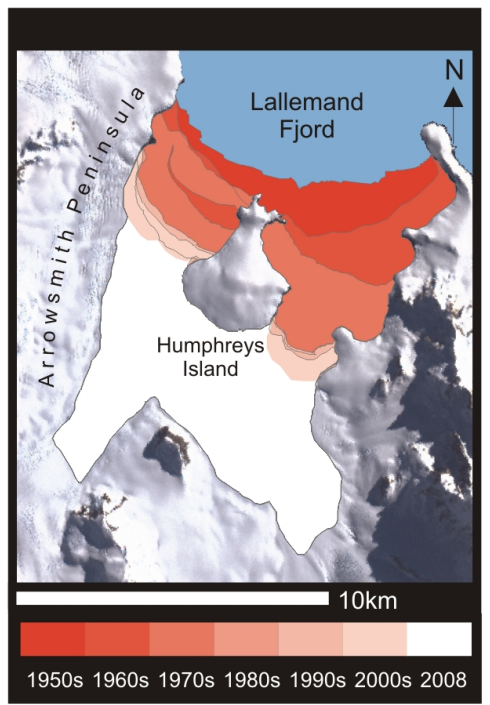

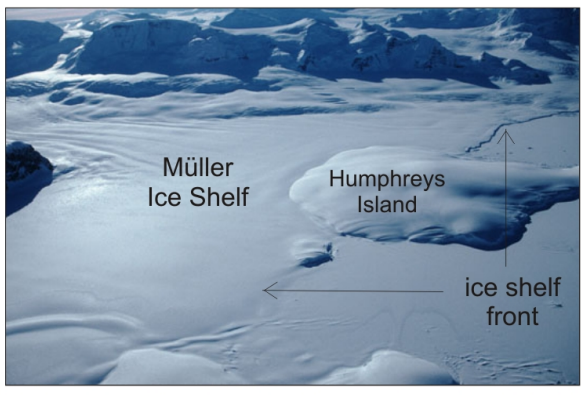

Humphreys Island and the edge of Müller Ice Shelf in January 1996 (D. Vaughan, BAS), looking south-west.

Ice shelf Area

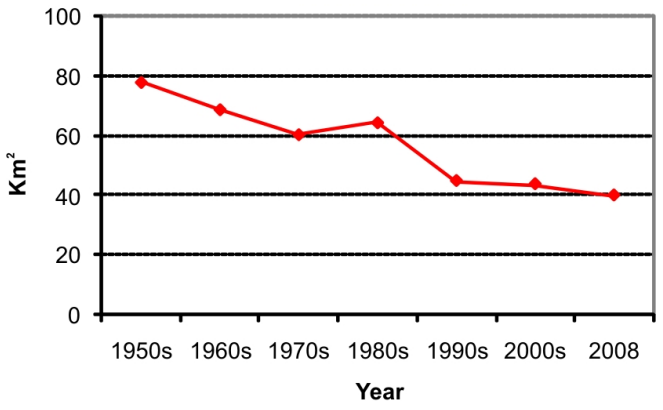

Fig. 4.1. Müller Ice Shelf

since the 1990s, the question remains, why does so much of Müller Ice Shelf remain today, when neighbouring Jones Ice Shelf (Fig. 1a) is entirely gone? Swithinbank (1986) suggested that without the protection afforded by the fjord embayment Müller Ice Shelf probably would not exist under present climatic conditions. This could offer some of the answer, but it might also be wise to question how much of the remaining portion of Müller Ice Shelf is actually floating. The photograph shown in Fig. 4.1 seems to show that only the western ice front as a clear calving front and it is possible that east of Humphreys Island, the ice is more ice plain than ice shelf. However, with water depths immediately adjacent to the ice shelf reaching over $600 \mathrm{~m}$ (Domack et al., 1995) this would seem to imply a surprising bed topography.

\subsubsection{Jones Ice Shelf (Fig. 4.2)}

(For a description of the full coastal-change time series for Jones Ice Shelf see Ferrigno, et al., 2006, p. 8; Fox and Vaughan, 2005). Jones Ice Shelf $\left(67^{\circ} 30^{\prime} \mathrm{S}\right.$ and $\left.66^{\circ} 55^{\prime} \mathrm{W}\right)$ filled Jones Channel between Bigourdan Fjord and Bourgeois Fjord, and was fed mainly by the 10-km long Heim Glacier on Arrowsmith Peninsula. Although substantially smaller than most $\left(29 \mathrm{~km}^{2}\right.$ in 1947), it has shown a similar pattern of retreat to other ice shelves on the Antarctic Peninsula. Including records prior to the 1950 s, the imagery reveals there was a slight increase in area between 1947 and 1978 , since when it began a rapid retreat, culminating in complete disappearance by 2003. Blaicklock Island and the Arrowsmith Peninsula are now separated by open water in Jones Channel.

However, despite being less than ten kilometres apart and under similar climate forcing, the east and west portions of the ice shelf behaved differently, with most of the early advance and subsequent retreat occurring on the eastern ice front. The western front was stable until the early 1990s, after which it too retreated, disconnecting from Blaicklock Island sometime between December 1998 and January 2001. The difference in response between the two ice fronts was examined by Fox and Vaughan (2005). Their conclusion was that the response of the east and west fronts of the ice shelf were controlled by the configuration of the fjord in which the ice shelf lay. They also concluded that the western and eastern portions of Jones Ice Shelf lie in convergent and divergent embayments respectively, and therefore had different strain rate regimes, which affected the retreat rates. This supports modelling studies (Doake et al., 1998) which compared contrasting ice flow regimes in the Larsen B Ice Shelf prior to its collapse. The course of retreat therefore, appears to be controlled not only by climatic events but also, in this case, the geometry of the embayment and the presence of a small ice rise that acted as a pinning point on the western side (Fox and Vaughan, 2005). 
Jones Ice Shelf
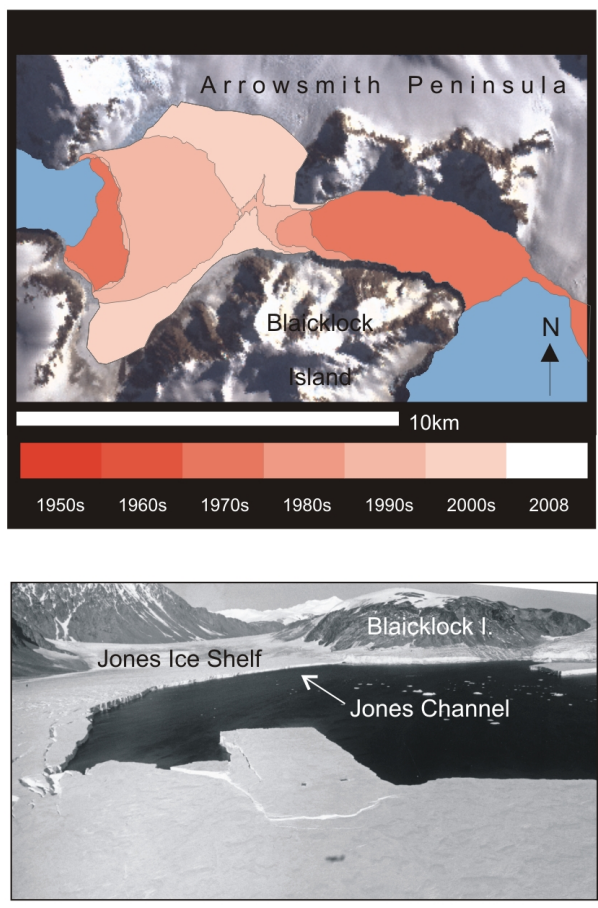

Image of Jones Ice Shelf taken during its retreat in 1998 (photographer unknown), looking east. Two depots of fuel drums are visible on the calving iceberg in the centre of the frame.

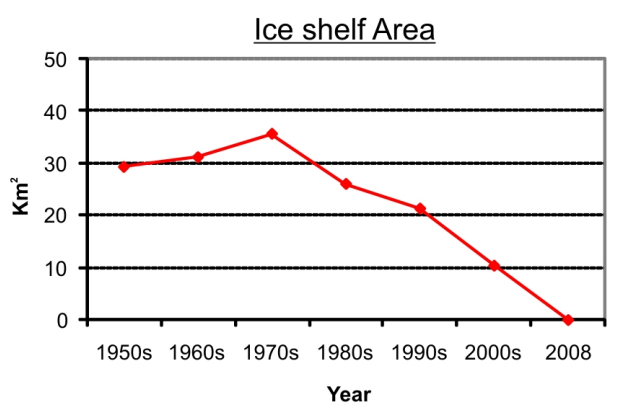

Fig. 4.2. Jones Ice Shelf

Ice-shelf thickness does not appear to have had a strong influence on the progress of the retreat (Fox and Vaughan, 2005). There is, however, insufficient evidence to determine whether surface-melting may be related to specific retreat events (Scambos et al., 2000).

\subsubsection{Wordie Ice Shelf (Fig. 4.3)}

(For a description of the full coastal-change time series for Wordie Ice Shelf see Ferrigno, et al., 2006, 8). Wordie Ice Shelf $\left(69^{\circ} 10^{\prime} \mathrm{S}, 67^{\circ} 30^{\prime} \mathrm{W}\right)$, the northernmost large (> $1000 \mathrm{~km}^{2}$ ) shelf on the western AP, disintegrated in a series of events during the 1970s and 1980s, and by 1992 there was little more than a few disconnected and retreating glacier

\section{Wordie Ice Shelf}
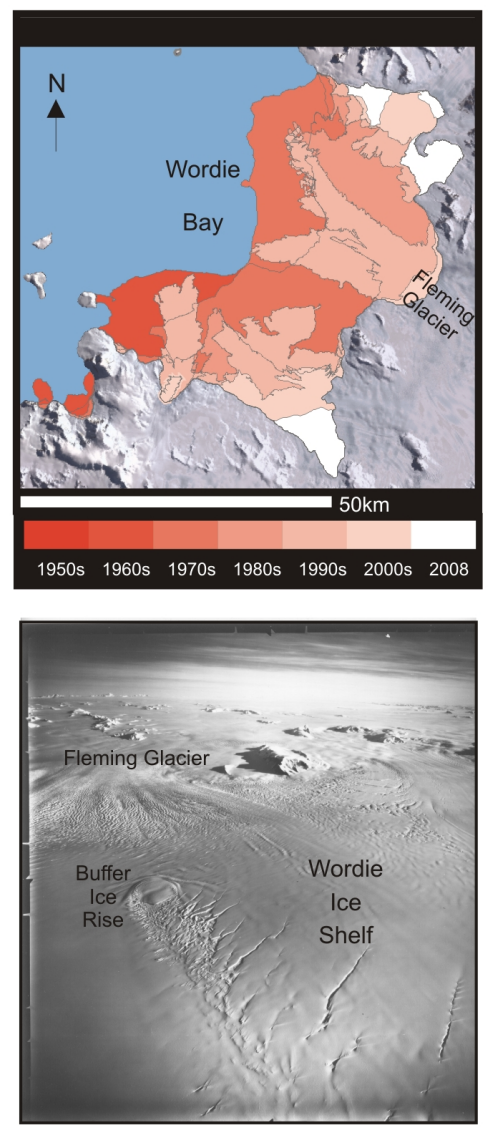

Wordie Ice Shelf seen from U.S. Navy trimetrogon oblique aerial photograph (TMA 1835, F33:74) on 28th November 1966 (courtesy of U.S. Geological Survey). The view is to the east.

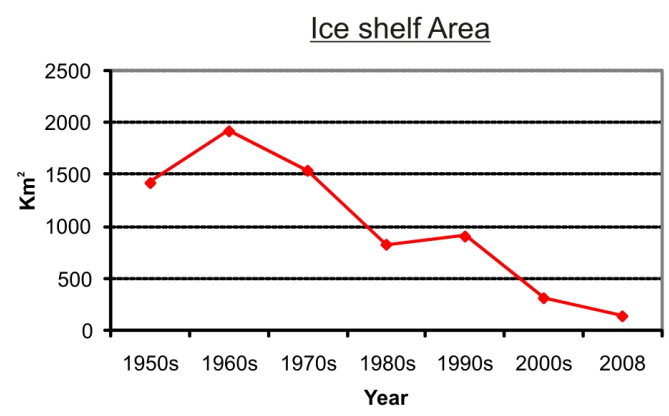

Fig. 4.3. Wordie Ice Shelf

tongues remaining. It was the most dramatic observed retreat of all ice shelves on the AP up until that time. Understanding the cause and mechanism of collapse has yielded important clues as to the behaviour of ice shelves as they undergo progressive ice front retreat. 
During the British Graham Land Expedition (1934-1937), the early explorers identified approximately ten ice rises or ice rumples. The ice shelf was then interpreted as a relict feature and because of poor surface conditions it was suggested that it would not survive for long (Fleming, 1940).

Doake and Vaughan (1991b) suggested that the breakup was triggered by the warming trend in mean annual air temperatures in this region since the early 1970s, which increased ablation and the amount of melt-water. In particular they briefly suggested that an increased prevalence of meltwater could either reduce fracture toughness of the ice shelf, or increase water pressure at the base of crevasses and allow them to grow into rifts; either of these processes, they suggested, could have increased the calving rate and caused the ice shelf to retreat. They also suggested that the major ice rises appeared to have played a significant role in controlling the retreat of Wordie Ice Shelf. The earlier ice front retreat was punctuated by periods of stasis when the ice was pinned on the ice rises (Vaughan, 1993), and the retreat between periods of stasis was rapid. The ice rises also appear to have acted as wedges, contributing to weakening of the ice shelf and hastening the break-up. As the shelf ice flowed past them, the ice rises caused splitting of the ice shelf upstream, and created broken wakes downstream, introducing weakness (see oblique aerial photograph in Fig. 4.3). The increasing stresses caused by the separation around the ice rise as the ice shelf accelerated eventually became sufficient for fracture. Fracture, in the form of surface crevasses or rifts extending to the bottom of the ice shelf, appeared prior to retreat of the ice front, but whether this was a cause or effect of the collapse remains unclear.

Wordie Ice Shelf was fed by a number of tributary glaciers which join to make three main input units. As the fracture processes weakened the interior of the ice shelf, and after the ice front had retreated past a critical point, the outlet glaciers appeared to punch through the remaining ice shelf because of the reduced restraint on them (Vaughan et al., 1993). However, the break-up of the ice shelf was not initiated by surging activity on the input glaciers.

Vaughan (1993) also concluded that there were no changes in the relative dominance of the tributary glaciers (between 8 to $20 \mathrm{~km}$ upstream) following the ice-shelf collapse and therefore the ice shelf provided no significant restraint on the inland glaciers. Given recent work, however, this conclusion is now in doubt. The impact of the loss of the ice shelf has been observed upstream on Fleming Glacier (Rignot et al., 2005). Satellite radar interferometry data from 1995 to 2004 and airborne ice thickness data from 2002 reveal that $50 \mathrm{~km}$ from its ice front, Fleming Glacier flows 50 percent faster than it did in 1974, prior to the main collapse of the Wordie Ice Shelf. Rignot et al. (2005) conclude that the glaciers accelerated following ice-shelf removal and have been thinning and losing mass to the ocean over the last decade.

\subsubsection{George VI Ice Shelf (Fig. 4.4)}

George VI Ice Shelf is the largest ice shelf on the west coast of the AP, covering a total area of $\sim 24000 \mathrm{~km}^{2}$. It is unusual in two respects, as discussed in Smith et al., 2007. Firstly, it has two ice fronts that are almost $500 \mathrm{~km}$ apart and experience quite different climatic conditions. Secondly, it is an ice shelf that is constrained within a narrow channel $(25 \mathrm{~km}$ wide in the north, widening to over $70 \mathrm{~km}$ in the south) and loses most of its mass to melting (both surface melt-pools and basal melting), rather than changes in ice-dynamics brought about by a changing calving rate (Roberts et al., 2005).This suggests that this ice shelf may be more sensitive to changes in ocean conditions, and less sensitive than its neighbours to atmospheric change (Doake and Vaughan, 1991b).

Both the north and south ice fronts have shown retreat in recent decades but the overall area has not shown significant change, currently at $92 \%$ of its original size (in 1947). Although the relative change is small, it has been argued that it may be in its first stage of disintegration (Luchitta and Rosanova, 1998).

The northern front (at $70^{\circ} \mathrm{S}, 68^{\circ} 45^{\prime} \mathrm{W}$ ) showed a short period of advance between 1947 and 1960, followed by a major phase of ice-shelf retreat until 1980, then slower but continual retreat through to the present day. A total of $610 \mathrm{~km}^{2}$ of ice has been lost since 1947. It is thought that calving occurs along rifts and fissures which penetrate the entire depth of the ice shelf (approximately $100 \mathrm{~m}$ at the northern ice front) (Potter and Paren, 1985). Conversely, it is thought that calving here has, at least in the past, been affected by the occurrence of perennial and on occasion, semi-permanent sea-ice, which may prevent calving of ice when cracks form near the edge, and holds large icebergs within the channel for years. Modelling studies of Humbert (2007) showed that the stress regime along the northern ice front is very different from the one at the southern end. Doake (1982) commented that it was difficult to locate the true ice shelf front in images because of the fragmented shelf. Indeed, interpretations of the ice front from imagery in 1974 in this study differ from those by Luchitta (1998).

The southern front (at $73^{\circ} \mathrm{S}, 72^{\circ} 10^{\prime} \mathrm{W}$ ) has shown a regular rate of retreat since 1947 , although retreat has slowed since the 1990s. It has lost a total of $1330 \mathrm{~km}^{2}$ since 1947 , more than twice the area of that lost from the northern front. It also appears to have begun retreating earlier, without any significant re-advance. Here the ice shelf is significantly thicker (a maximum of $600 \mathrm{~m}$ ) and wider (over $70 \mathrm{~km}$ ) than at the northern front (Smith et al., 2007). There is little sea-ice build-up within the Ronne Entrance which also differs from the northern end of George VI Sound.

An unusual abundance of annual melt ponds on parts of George VI Ice Shelf has been known, at least since the 1960s (Wager, 1972). In recent decades, every summer much of the southern part of the ice shelf has been covered in melt-ponds that tend to recur on the same area of ice each year. This is 


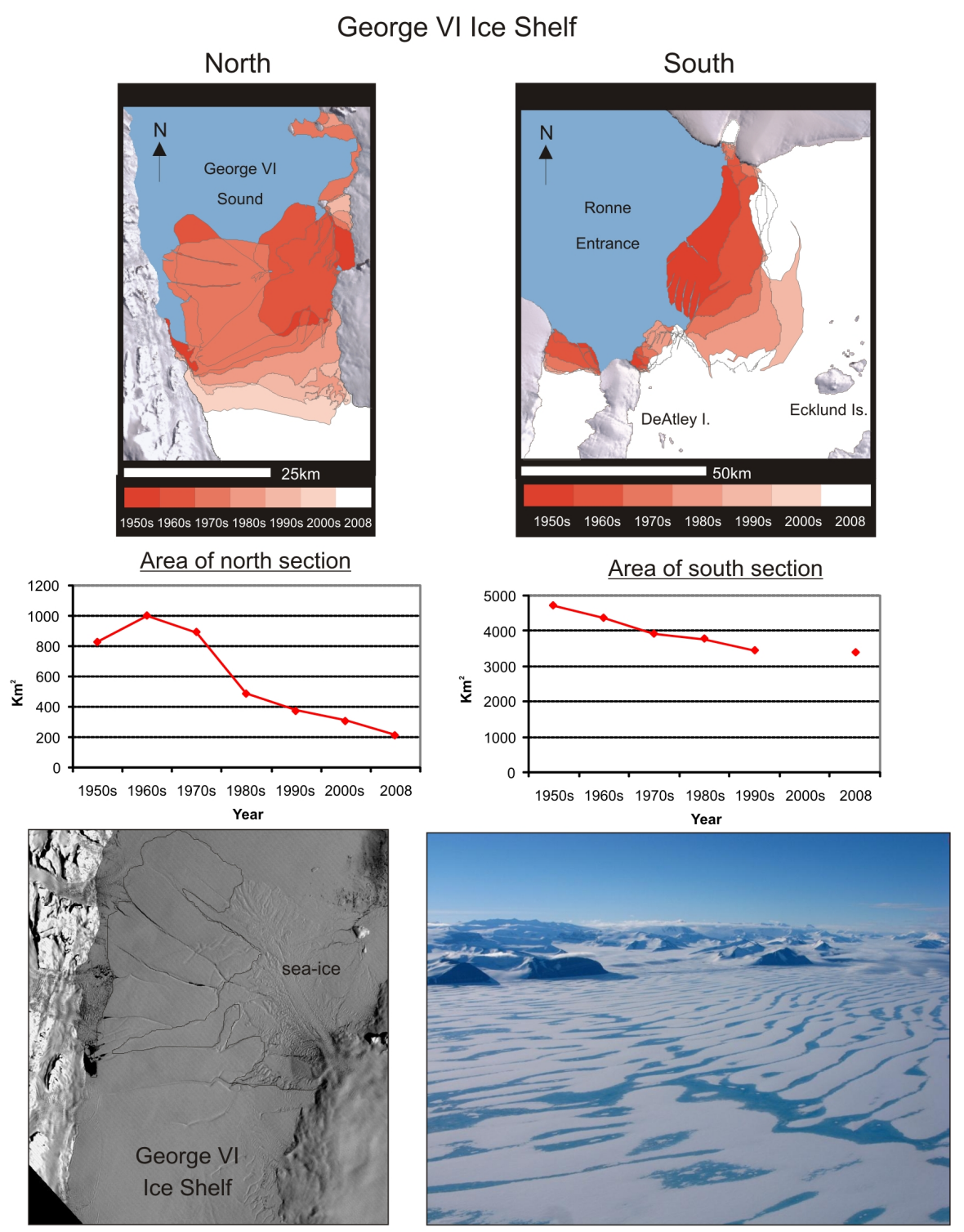

Landsat MSS image (NASA Band 7 Path/Row 233/109: 3rd February

Surface melt pools in January 2009 (A. Cook, BAS)

1979) showing north ice front

locked in place by sea-ice
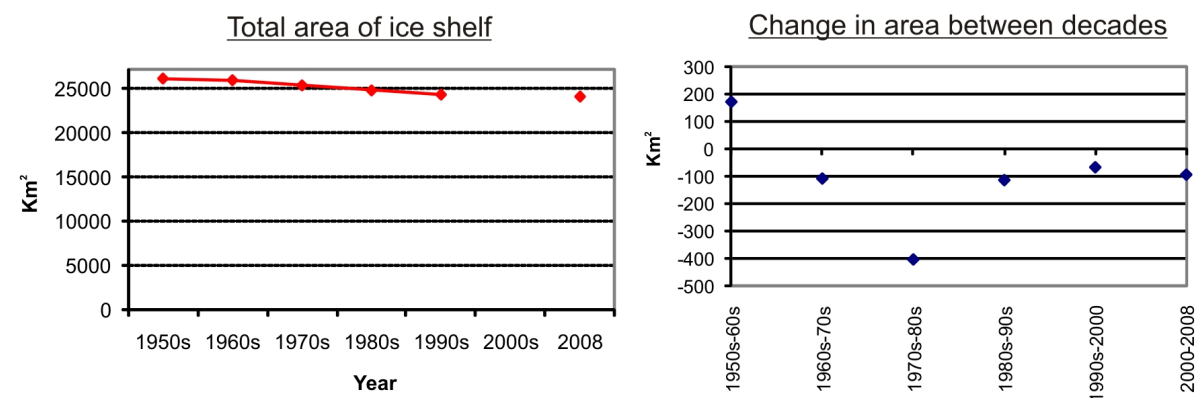

Fig. 4.4. George VI Ice Shelf 
clear evidence that the presence of persistent melt does not necessarily condemn an ice shelf to rapid retreat, and cannot be considered the sole factor in causing ice-shelf retreat. Extensive surface melting in the summer season may be triggered by loose sedimentary rock particles that are blown onto the ice surface from the surrounding mountains (Wager, 1972; Ridley, 1993). There is one major factor, however, that is likely to be responsible both for the persistence of meltponding on George VI Ice Shelf and its continued survival. Most of the ice in George VI Ice Shelf derives from glaciers feeding it from the Antarctic Peninsula in the east. Most of this ice flows towards Alexander Island to the west (Pearson and Rose, 1983), creating strong uniaxial compression over large portions of the ice shelf. Being in compression means that there are few crevasses in the ice shelf, and these, and any other routes by which water can drain down out of the ice shelf, are quickly closed. Melt water thus tends to remain at the surface of this ice shelf much longer than is normal. In the absence of extensional strain, surface ponding appears to be insufficient to cause fracturing.

The overall pattern of retreat of both ice fronts coincides with the well-documented atmospheric warming across the AP, but since the southern ice front retreat preceded retreat at the northern ice front, it cannot be interpreted simply as a result of the southern migration of a key mean annual isotherm (Smith et al., 2007). It is likely that the southern ice front is also responding to other forcing mechanisms and feedbacks (e.g. changes in sea-ice extent or oceanography). One theory is that the mass balance of the ice shelf is strongly influenced by high basal melt rates associated with intrusions of warm Upper Circumpolar Deep Water (UCDW) (Shepherd et al., 2003; Payne et al., 2004) and therefore its stability is sensitive to changes in ocean circulation. The thinning of floating glaciers in the West Antarctic Ice Sheet (WAIS) region has been attributed to heat contained within the CDW flowing towards the continent via a submarine glacial trough and driving basal melting (Walker et al., 2007). In order to assess whether George VI Ice Shelf has entered a phase of rapid retreat and whether this is largely driven by atmospheric warming, basal melting, or both, requires further work (Smith et al., 2007).

\subsubsection{Wilkins Ice Shelf (Fig. 4.5)}

(For a description of a coastal-change time series for Wilkins Ice Shelf over the past 15 years, see Braun, et al., 2009). Wilkins Ice Shelf $\left(70^{\circ} 20^{\prime} \mathrm{S}, 72^{\circ} 20^{\prime} \mathrm{W}\right)$ is the largest ice shelf on West Antarctica currently undergoing significant break-up. There is little data available between 1947 and mid-1980s, but the earliest retreat was noted by Braun et al. (2009) to have occurred in 1991. As with the Larsen A and Larsen B Ice Shelves (see 4.2.2), the retreat events were characterized by episodic calving of many small elongated icebergs. A break-up event was observed in 1998 (Scambos et al., 2000) but much of the ice remained until March, and
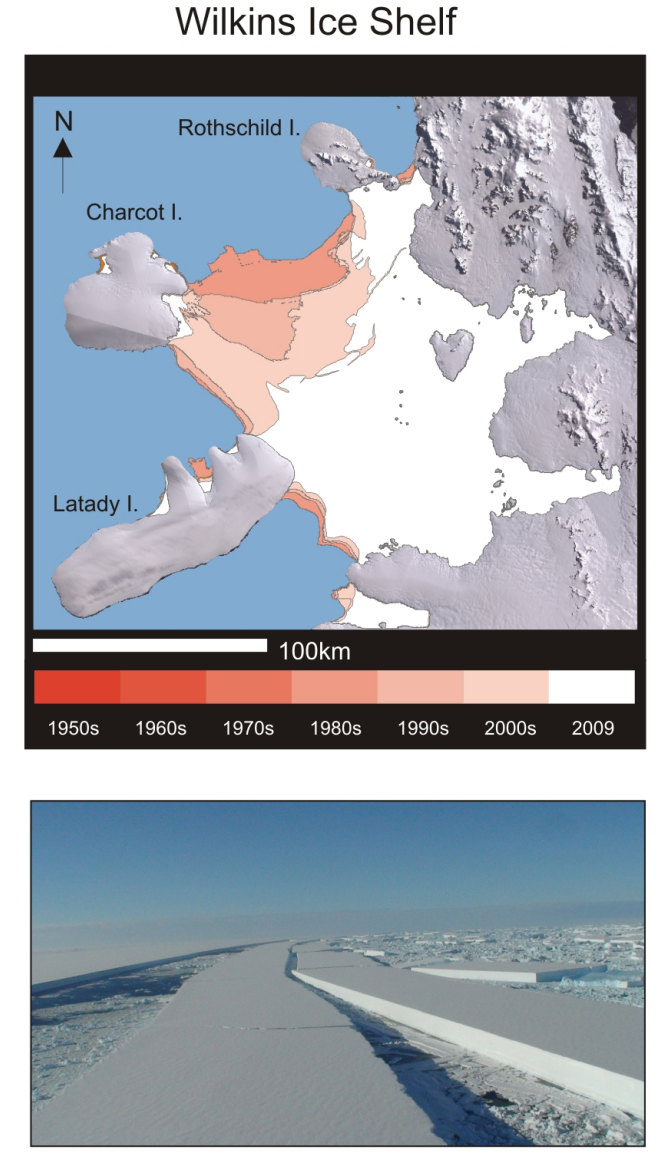

Tabular ice bergs calving from the edge of Wilkins Ice Shelf during break-up in March 2008 (J. Elliot, BAS)

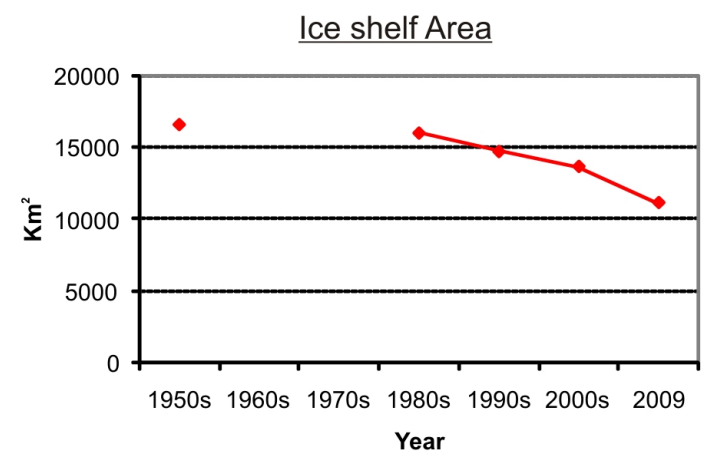

Fig. 4.5. Wilkins Ice Shelf

again in July, 2008, when dramatic calving occurred. The ice shelf was then only supported by a single strip of ice just $1 \mathrm{~km}$ wide, strung between Latady and Charcot islands. This strip gave way in April 2009, reducing the overall area to $5434 \mathrm{~km}^{2}$, less than two thirds of the original area. This number is that measured for this study and at that particular time for an ice shelf that is constantly evolving: other studies have given a more detailed description of the area changes that 
have occurred over the past few years (e.g. Braun and Humbert (2009), Humbert and Braun (2008), Braun et al. (2009) and Scambos et al., 2009).

Wilkins Ice Shelf has an unusual mass balance regime and differs in many ways from its neighbours, Wordie Ice Shelf and George VI Ice Shelf, which are fed by glaciers. It is unusually stagnant with interior flow rates of $30-90 \mathrm{ma}^{-1}$, compared to Wordie (typically, 200-2000 $\mathrm{ma}^{-1}$ ) and George VI (typically, $<200 \mathrm{ma}^{-1}$ ) (Vaughan et al., 1993). The catchment area is approximately $16900 \mathrm{~km}^{2}$, which is an unusually low proportion of grounded ice sustaining the ice shelf, compared with Wordie Ice Shelf and George VI Ice Shelf. In this respect it may be similar to Larsen A Ice Shelf in being sustained largely by in situ accumulation. Vaughan et al. (1993) also found that in the middle of the ice shelf the surface was low, but there is a topographic bulge along the shelf's western margins, where most of the accumulation appeared to occur. Abundant melt-ponding and the observation that the ice shelf was unusually thin and parts may be brinesoaked to sea-level (Vaughan et al., 1993; Swithinbank and Luchitta, 1986), suggested that the shelf may be subject to rapid break-up (Lucchitta and Rosanova, 1998). Vaughan et al. (1993) however, stated that Wilkins Ice Shelf front was likely to decay by normal calving processes and unlikely to undergo sudden disintegration (as seen in the Wordie Ice Shelf), at least until the calving front decoupled from the fringing islands. They speculated that if the climatic limit continued to move south at the same rate, within 30 years the Wilkins Ice Shelf may no longer be viable.

Analysis of the recent break-up suggested that surface or near-surface melt-water was the main pre-condition for disintegration, and that the opening of crevasses by the pressure of increasing volumes of melt-water, so-called hydro-fracture, was an important mechanism (Scambos et al., 2009). In parts of the ice shelf where extensional stresses were already high, hydro-fracture would have favoured the opening of crevasses until they eventually became rifts. Scambos et al. noted that the break-ups were characterized by repeated rapid fracturing that created narrow parallel blocks at the ice-edge, where icefront bending stresses induced by buoyancy forces were responsible for fracture formation. Braun et al. (2009) showed that stresses in Wilkins Ice Shelf changed with each major disintegration event, resulting in lengthening of rifts immediately following the events. These changes in stress distribution, together with widespread brine infiltration, led to the May 2008 disintegration event (Scambos et al., 2009). It has also been inferred that compressive stress along the narrow ice bridge between Charcot and Latady Islands increased as this region narrowed. Near-surface melt-water is effective at driving fracture extension and it has been concluded that most disintegration events will occur during or just after an extensive melt season. The two break-ups that occurred during Autumn/Winter seasons, however, showed that melt ponds played no role in these particular break-up processes (Braun and Humbert, 2009). The fact that Wilkins
Ice Shelf experienced two break-up events under two widely contrasting surface conditions reveals that there is more than one mechanism at play in its disintegration. Prediction of where and when the next step in the break-up might occur is impossible due to this highly complex pattern of fracturing, and close observation of subsequent events by satellite is key to examining the causes and triggers of break-up events (Humbert and Braun, 2008). Latest research (carried out in February 2009) suggests that about $3100 \mathrm{~km}^{2}$ at the northern Wilkins Ice Shelf are endangered, but that there is no visible signature that the remaining $8000 \mathrm{~km}^{2}$ are at risk (Braun et al., 2009).

In addition to climatic forcing (i.e. the migration southwards of the thermal limit of viability), the Wilkins Ice Shelf is subject to the same oceanic forcing mechanism as George VI Ice Shelf as it receives the same warm-water influx of the UCDW current. The major decrease in sea-ice extent observed in the Bellinghausen Sea from 1988 through 1991 may also have affected the ice-shelf margin, although this remains to be explored (Lucchitta and Rosanova, 1998).

\subsubsection{Other ice shelves on west Antarctic Peninsula (Fig. 4.6 and 4.7)}

There are two other substantial ice shelves located on the western side of the Antarctic Peninsula: Bach Ice Shelf, located between Beethoven Peninsula and Monteverdi Peninsula, at the southern end of Alexander Island, and Stange Ice Shelf, west of Spaatz Island. There are also a number of small un-named ice shelves close to the Wilkins Ice Shelf, on Beethoven Peninsula, which are not discussed in this report.

Although Bach Ice Shelf and Stange Ice Shelf are named and are considerably larger than other ice shelves on the AP (namely: Jones, Müller, Wordie, Prince Gustav and Larsen A), there has to date been very little discussion about either. There has been much greater interest paid to their neighbours, Wilkins Ice Shelf and George VI Ice Shelf.

They should be considered, however in studies of ice-shelf behaviour in this region, as they both display relative stability in an area that may be subject to both atmospheric and oceanic forcing. Bach Ice Shelf $\left(72^{\circ} \mathrm{S}, 72^{\circ} 20^{\prime} \mathrm{W}\right)$ lies between Wilkins Ice Shelf and George VI Ice Shelf southern ice front, both of which have shown significant retreat in recent years. Its area was $4800 \mathrm{~km}^{2}$ in 1947 and since then it has lost only $300 \mathrm{~km}^{2}$, showing a cycle of steady growth and intermittent calving retreat during this period. Stange Ice Shelf $\left(73^{\circ} \mathrm{S}, 76^{\circ} 40^{\prime} \mathrm{W}\right)$, situated to the west of George VI Ice Shelf, also shows no signs of retreat. At $8300 \mathrm{~km}^{2}$ in 1970s (there are no reliable records of the ice front position prior to 1973), it is currently at $8000 \mathrm{~km}^{2}$, or $96 \%$ of its original size. It can be concluded that both Stange and Bach Ice Shelves show stable ice-shelf behaviour. They both currently lie to the south of the $-9{ }^{\circ} \mathrm{C}$ Mean Annual Temperature (MAT) isotherm, but with retreat of the Wilkins Ice Shelf suggesting that this limit may be moving south, Bach 

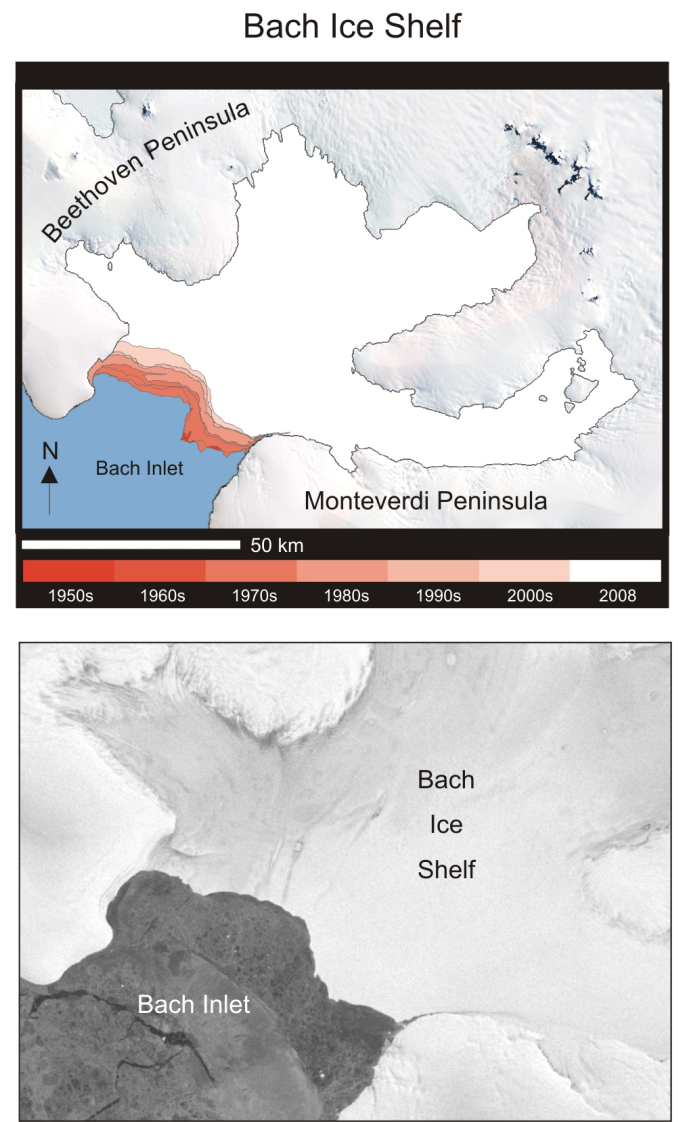

Radarsat Antarctic Mapping Project (1997) image of Bach Ice Shelf front. Image courtesy of National Snow and Ice Data Center (Liu et al., 2001).

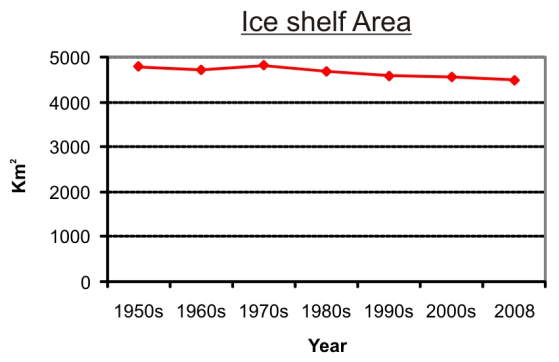

Fig. 4.6. Bach Ice Shelf

Ice Shelf may be the next ice shelf under threat. The impact of the UCDW current, which is speculated to be contributing to the ice loss at the George VI Ice Shelf southern front, is yet to be examined.

\subsection{East coast of the Antarctic Peninsula, north to south}

\subsubsection{Prince Gustav Ice Shelf (Fig. 4.8)}

(For a description of the full coastal-change time series for Prince Gustav Ice Shelf see Ferrigno, et al., 2006, 6-7). The Prince Gustav Ice Shelf $\left(64^{\circ} 20^{\prime} \mathrm{S}, 58^{\circ} 30^{\prime} \mathrm{W}\right)$ was the most
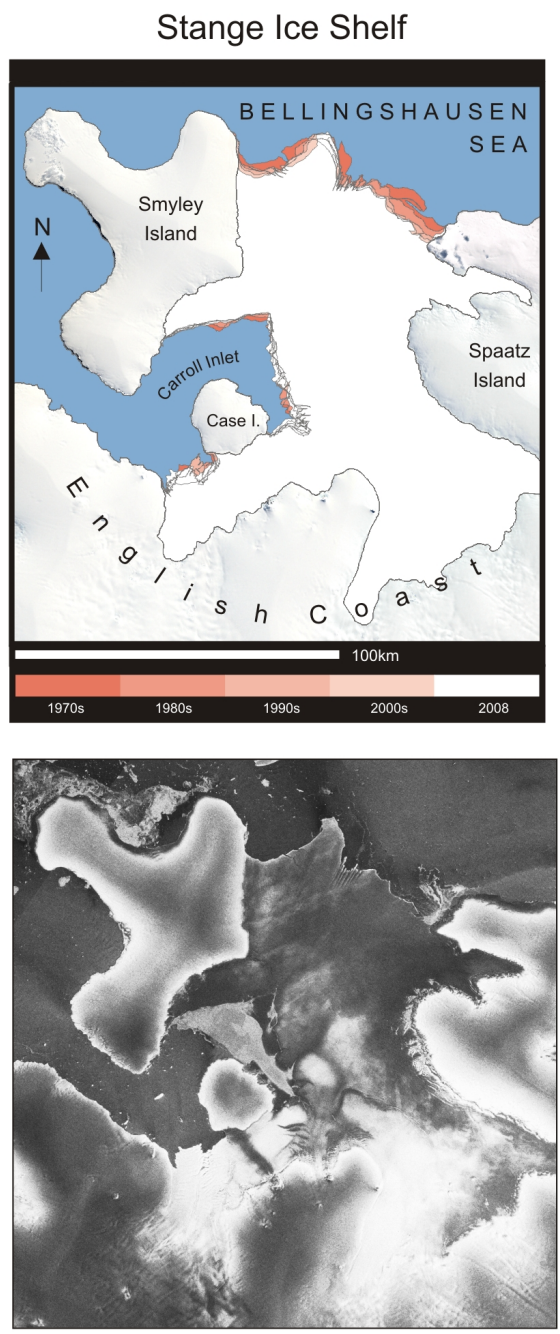

Stange Ice Shelf on 28th January 2009. Envisat ASAR image courtesy of European Space Agency.

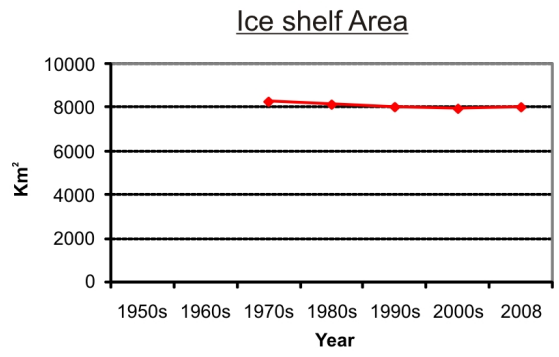

Fig. 4.7. Stange Ice Shelf

northerly ice shelf and was the first to show signs of retreat. Although $1600 \mathrm{~km}^{2}$ in 1957 , this ice shelf retreated progressively through the second half of the 20th century. In 1995, it finally collapsed, leaving open water between James Ross Island and the main Antarctic Peninsula. The remnants close to the coast have now also completely melted. 

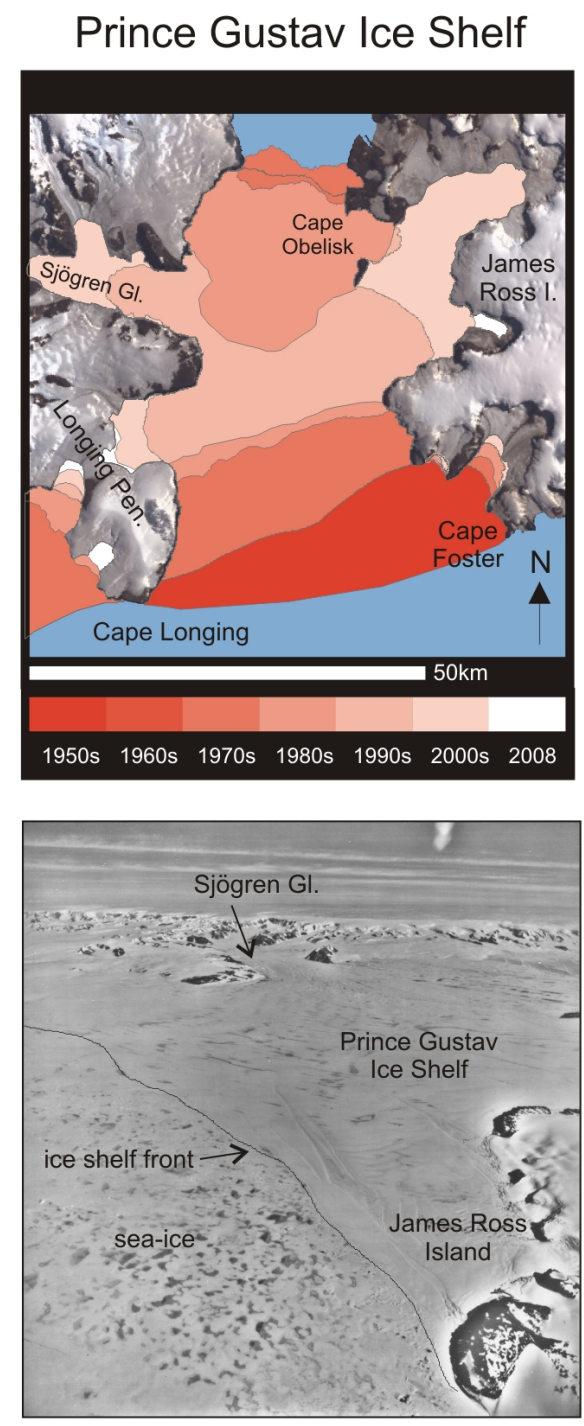

TMA oblique aerial photograph (2159, F33: 113) showing ice shelf between James Ross Island and Cape Longing in 1969, looking north-west (courtesy of U.S.G.S).

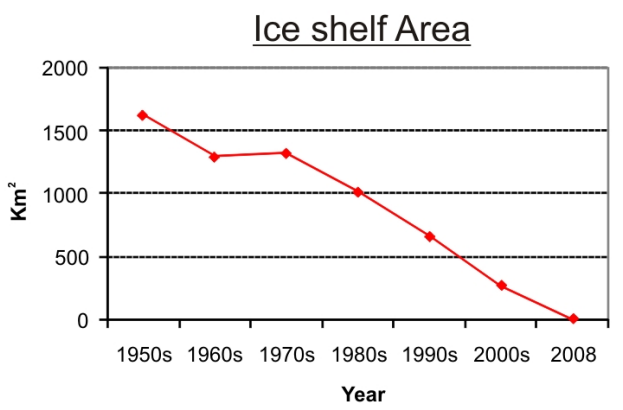

Fig. 4.8. Prince Gustav Ice Shelf
There is some evidence that Prince Gustav Ice Shelf was already retreating prior to 1957 , the first position recorded for this study. Historical accounts as far back as 1843 suggest that the ice shelf had been retreating for most of this period (Cooper, 1997). A study by Reece (1949), based on expedition reports, showed that in 1945 the southern ice front stretched from James Ross Island as far south as Robertson Island. He concluded that at this time the ice was continuous with Larsen Ice Shelf. He discussed the difference in the types of ice observed in the Prince Gustav Channel: "(The ice to the north of Sjögren Glacier) is land-fast sea ice, which persists for more than one season due to the presence of islands; that in the south is shelf ice of the same type and origin as the Larsen Ice Shelf but perhaps less thick. This is mainly due to the presence of shoals although islands are also there." There is evidence to suggest that the ice shelf became separated from Larsen Ice Shelf sometime in the late 1940s (Francis, 1947), retreating to Cape Longing. Since then there was a rapid retreat from 1957 to 1961, followed by a more steady retreat until the collapse in 1995.

As with Jones Ice Shelf, the response of the ice fronts at each side of the channel differed considerably. The northern ice front was relatively stable until the early 1990s, but the southern ice front has shown a slow progressive retreat since the earliest records. The mechanisms underlying the retreat were discussed by Cooper (1997). The ice of the Prince Gustav Channel has two components: glacier tongues (flowing into the northern part of Prince Gustav Ice Shelf) and ice derived from in situ accumulation (south of Sjögren Glacier). The different geometries may also explain the differing stability of the northern and southern margins: in the north, the land margins are convergent and the ice margin is pinned at the narrows between Cape Obelisk and the opposite shore; in the south the land margins are broadly divergent, allowing the ice to retreat steadily along a featureless coast (Cooper, 1997). The geometry of the southern coast has changed due to the significant retreat of Sjögren Glacier, making it unlikely that the ice shelf will reform.

One study of sub-ice-shelf sediments has demonstrated that Prince Gustav Ice Shelf varied in extent in response to natural Holocene climate forcing (Pudsey and Evans, 2001). This study concluded that ice shelves in this region are sensitive indicators of regional climate change, but without necessarily implying that recent decay is due to human-induced climate change (Pudsey and Evans, 2001). 


\subsubsection{Larsen A and Larsen B Ice Shelves ${ }^{2}$ (Fig. 4.9 and 4.10)}

(For a full time series of retreat for Larsen Inlet and Larsen A see Ferrigno, et al., 2006, 7 and Skvarca, 1999. For Larsen B see Ferrigno et al., 2008, 8. For a detailed analysis of Larsen Ice Shelf changes in extent between 1840 and 1960, see Karstkarel, 2005). Close to the Prince Gustav Ice Shelf, the Larsen A Ice Shelf $\left(64^{\circ} 40^{\prime} \mathrm{S}, 60^{\circ} \mathrm{W}\right)$ has also disappeared. Larsen A Ice Shelf extended from Cape Longing to Robertson Island and merged with Larsen B Ice Shelf to the south at Seal Nunataks. At $4000 \mathrm{~km}^{2}$ in 1961, Larsen A remained relatively stable until the 1980 s, when it began to retreat in steps, culminating in January and February 1995 in a major collapse. During this period, almost $2000 \mathrm{~km}^{2}$ of ice shelf were lost within a few weeks, breaking up into thousands of icebergs producing a plume $200 \mathrm{~km}$ into the Weddell Sea. This breakup was the most spectacular event of ice-shelf retreat along both coasts of the Antarctic Peninsula until that time, and was the first collapse that was properly observed (Rott et al., 1996, 1998). The ice within Larsen Inlet (between Cape Longing and Sobral Peninsula) also continued to retreat after it became disconnected from Larsen A Ice Shelf, suffering major retreat during the period 1987 to 1989 , and very little ice remains. What does remain is a small promontory held together by Seal Nunataks, which may or may not be floating.

The same form of collapse occurred on an even larger scale in 2002 with the break-up of Larsen B Ice Shelf. Larsen B $\left(65^{\circ} 30^{\prime} \mathrm{S}, 61^{\circ} \mathrm{W}\right)$ is the ice shelf south of Larsen A, extending from Robertson Island in the north to Jason Peninsula in the south. In 1963, it was $12000 \mathrm{~km}^{2}$ but now has only $20 \%$ of its area remaining $\left(2400 \mathrm{~km}^{2}\right)$. Most of the remaining ice is held in Scar Inlet, between Cape Disappointment and Jason Peninsula. Unlike Larsen A, Larsen B continued to advance until the early 1990s. A large tabular iceberg $\left(\sim 1700 \mathrm{~km}^{2}\right)$ and smaller icebergs calved in 1995, after which it followed a similar pattern of retreat to its neighbour Larsen A (Scambos et al., 2000). It culminated in a dramatic fragmentation of approximately $3250 \mathrm{~km}^{2}$ within only a few days in February 2002. This was the first ice shelf for which good data was collected prior to retreat, assisting with understanding the controls of the dynamics of ice shelves.

The potential mechanisms leading to the disintegration of these ice shelves have been widely discussed. The underlying cause appears to be rising atmospheric temperatures in the region (Rott et al., 2002, 1998; Vaughan et al., 2001; Skvarca et al., 1998; Domack et al., 2005), but while this may be the principal driver, it does not explain the mechanism behind dramatic collapse rather than normal progressive retreat.

\footnotetext{
${ }^{2}$ There are four glaciological distinct sections of the feature that is formally named "Larsen Ice Shelf", these have been termed Larsen A, Larsen B, Larsen C and Larsen D following nomenclature proposed by Vaughan and Doake, 1996. See Fig. 1a.
}

Both ice shelves were observed to have significant meltwater accumulation, both immediately prior to and in preceding melt-seasons. One theory is that the build-up of surface melt-water causes initial fragmentation of the ice shelf by downward propagation of water through crevasses (Scambos et al., 2000, 2008; van der Veen, 2007; van den Broeke, 2005). The rapid disintegration of the rifted shelves into thousands of small fragments could be explained by a secondary process proposed by MacAyeal et al. (2003). This involves energy being released when narrow ice-shelf fragments capsize in a coherent manner, which then initiate further fragmentation in a "domino" effect. This mechanism could also help explain the time delay between previous seasons of greatest melt-water build-up and the season of rapid collapse. The pre-break-up surface texture and ice thickness, which are related to the glacier source areas, are also critical in determining the speed of ice-shelf disintegration (MacAyeal et al., 2003).

Another theory, supported by numerical modelling of the changing stress regime during the collapse of Larsen A (Doake et al., 1999), suggests that the geometry of the ice front could be extremely significant in initiating disintegration. The theory holds that an ice front may be kept stable only so long as there remains an arch of horizontal uniaxial compression that bridges the pinning points on the ice front. The arch of compression in the ice shelf are similar to the vertical-plane forces that maintain the arch of a stone bridge; here the lower stones are held in compression, but if too many stones fall away from the underside and the arch is breached the bridge will inevitably collapse. Similarly, in an ice shelf, so long as the second principal stress (perpendicular to the ice front) is compressive the ice front can remain stable, but when calving causes the geometry to bow inwards and removes sufficient ice from this compressive arch (Doake et al., 1998; Rack et al., 2000), the ice shelf front could become potentially unstable. Under these conditions irreversible retreat will occur, possibly catastrophically (Doake et al., 1998). On Larsen B Ice Shelf, large rifts, almost parallel to the ice front, formed lines of weakness along which calving occurred in the years prior to collapse (Skvarca, 1993). These transverse compression fractures differ from the linear fractures that appeared in Wilkins Ice Shelf prior to collapse, suggesting there is a difference in calving mechanisms.

Another hypothesis has been used to suggest that the ice shelves may have become susceptible to crevasse-fracture through a sustained ice thinning (Shepherd et al., 2003). Satellite altimetry has shown that Larsen B Ice Shelf lowered by up to $0.17 \pm 0.11 \mathrm{ma}^{-1}$ between 1992 and 2001 , which could be explained not only by increased summer melt-water changing the near surface density structure, but the loss of basal ice through melting (Shepherd et al., 2003). This suggests that enhanced ocean-driven melting could provide a link between regional climate warming and successive disintegration of these sections of the Larsen Ice Shelf. Oceanographic observations in this region are limited, 


\section{Larsen A Ice Shelf}
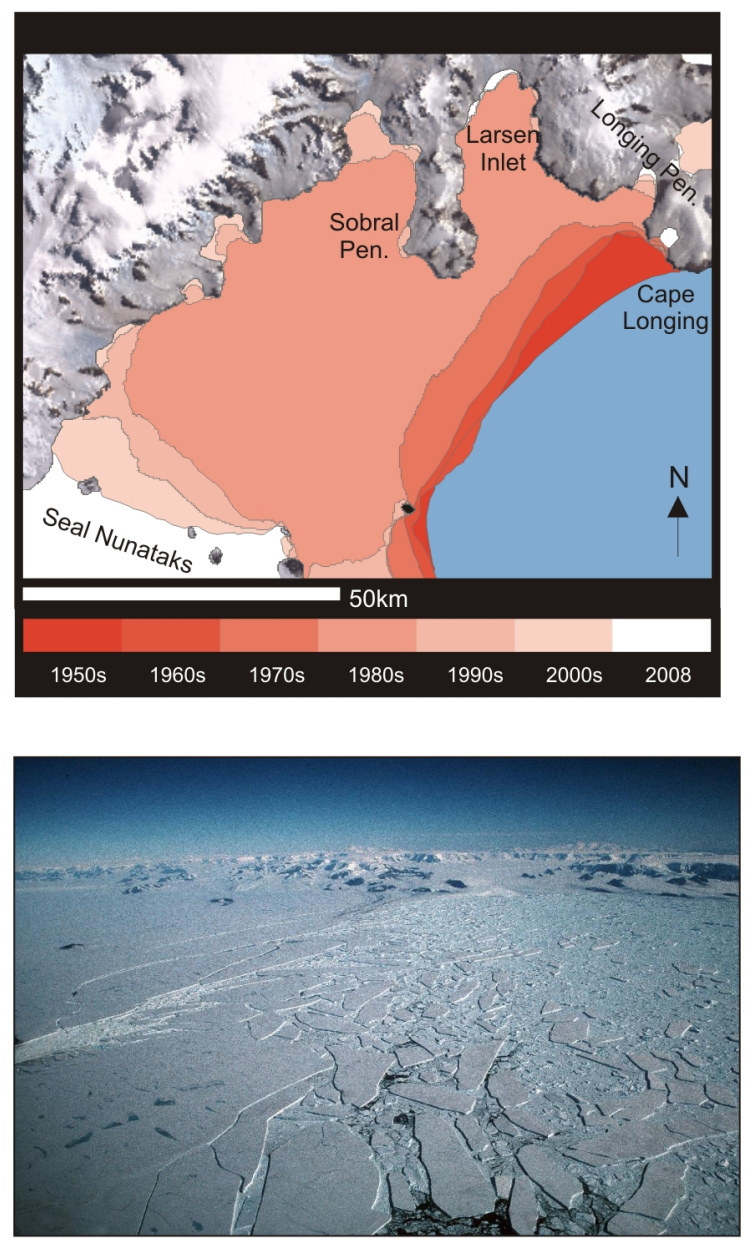

Thousands of small icebergs seen from a BAS Twin otter during the major collapse event in January 1995 (P. Wragg, BAS)

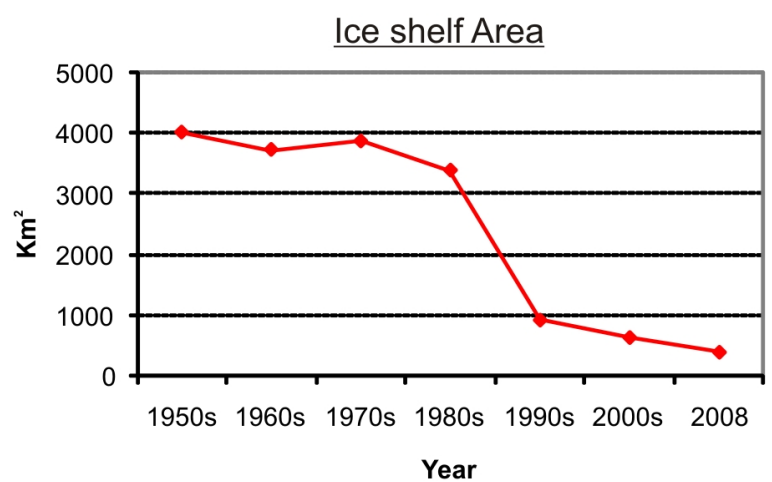

Fig. 4.9. Larsen A and Larsen Inlet Ice Shelves

\section{Larsen B Ice Shelf}
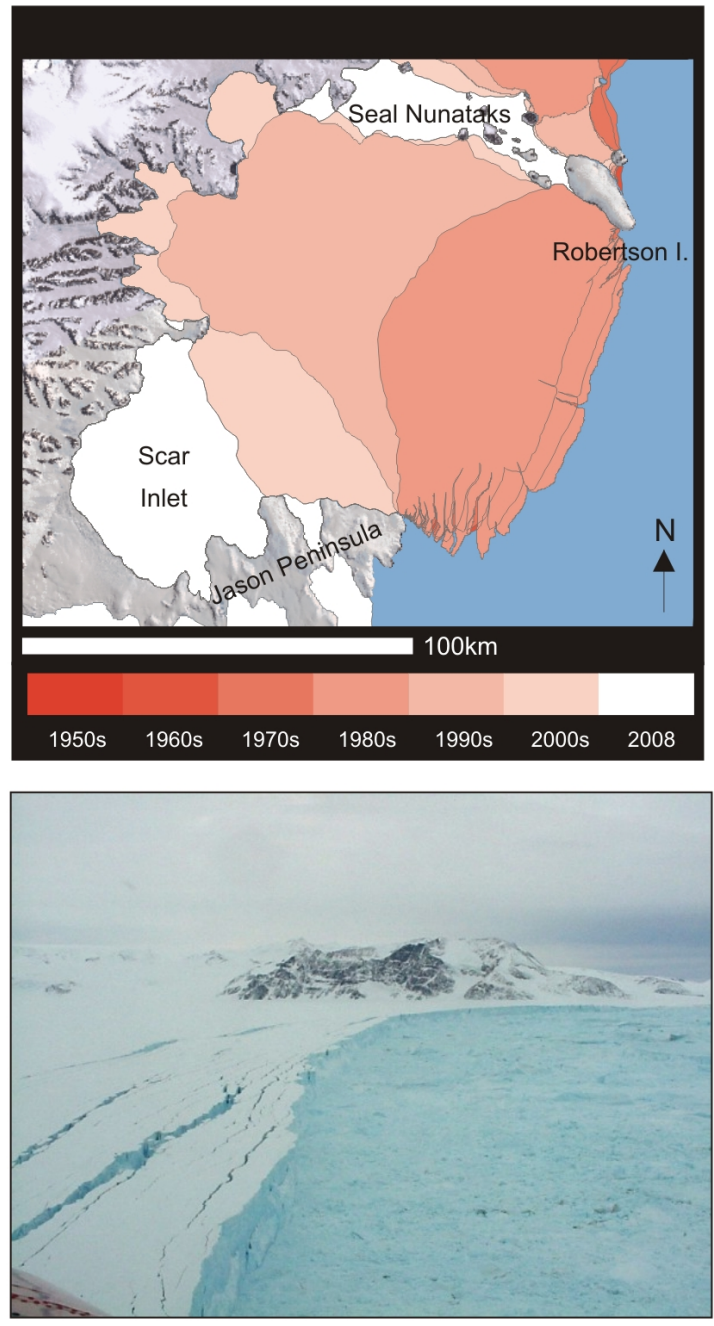

Larsen B ice front during major collapse event, taken on 13 March 2002 (S. Tojeiro, Argentine Air Force)

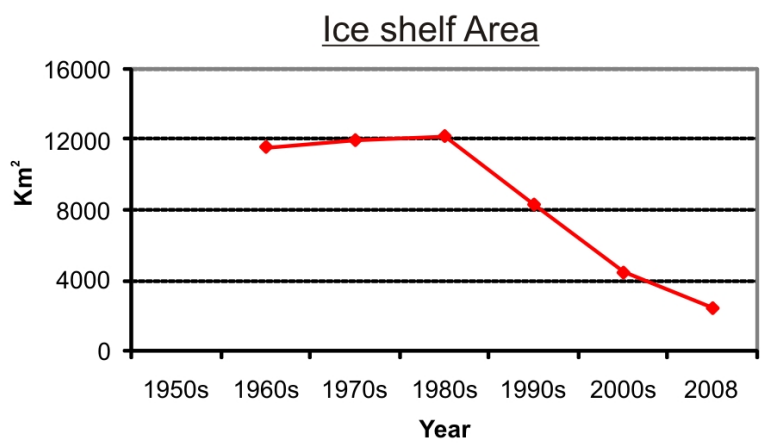

Fig. 4.10. Larsen B Ice Shelf 
however, and another study has shown that regional ocean warming may not have had a major impact on basal melt rates (Nicholls et al., 2004).

Other changes in the ice-shelf dynamics prior to their collapse have also been detected, such as an acceleration in iceshelf flow of up to $50 \%$, revealed through observations using satellite radar interferometry for the Larsen B Ice Shelf (Rignot et al., 2004; Vieli et al., 2006; Skvarca et al., 2003). It has been speculated that the ice-shelf acceleration is explained by the retreat of the ice front but also by further rheological weakening of the shear margins, and not by the observed thinning or the acceleration of tributary glaciers (which appear to be an effect, not a cause of ice-shelf acceleration) (Vieli et al., 2007; Khazendar et al., 2007). Ice surface features were examined by Glasser and Scambos (2008), who concluded that structural glaciological discontinuities played a large part in the break-up of the Larsen B Ice Shelf because they rendered the ice shelf mechanically weak prior to its collapse. Large open-rift systems, which were not present more than $\sim 20$ years ago, became more pronounced in the years preceding break-up, possibly as a result of ice-shelf front retreat during 1998-2000 which removed the strongest portions of shelf ice (Glasser and Scambos, 2008).

These changes indicate that the Larsen A and Larsen B ice shelves reacted to the changing climate significantly before their collapse. The causes of these pre-collapse changes and their link to the changing climate, however, are still poorly understood. It is accepted that rapid regional warming has been occurring on the Antarctic Peninsula over the last 50 years, at a rate of $3.7 \pm 1.6^{\circ} \mathrm{C}$ per century (Vaughan et al., 2003). The steady retreat and collapse of the northern Larsen Ice Shelf coincided with this warming trend on the east coast (Skvarca et al., 1998). In 2006, the first direct evidence linking human activity to the collapse of Larsen ice shelves was reported (Marshall et al., 2006). That study showed that the Southern Hemisphere Annular Mode has been enhanced by greenhouse gas emissions, and has had a profound effect on AP summer temperatures by causing warm Föhn winds to blow off the Antarctic Peninsula. If warming continues, the Larsen $\mathrm{C}$ may soon display a similar pattern of retreat.

\subsubsection{Larsen C Ice Shelf (Fig. 4.11)}

Larsen C Ice Shelf $\left(67^{\circ} 30^{\prime} \mathrm{S}, 62^{\circ} 30^{\prime} \mathrm{W}\right)$ is the largest ice shelf on the AP, currently at just under $51,000 \mathrm{~km}^{2}$. It extends from Jason Peninsula in the north to Gipps Ice Rise in the south, where it merges with Larsen D Ice Shelf. To date, this ice shelf has not shown evidence of climate driven retreat, as the variations in the ice front follow normal ice-shelf fluctuation patterns.

There has been relatively little discussion about Larsen C Ice Shelf compared with its neighbours, Larsen A and B. Skvarca (1994) described changes in the ice-shelf margins and surface-ice features along the Larsen Ice Shelf from Cape Longing as far south as Ewing Island. He noted ad- vance along the area $\sim 70 \mathrm{~km}$ southeast of Jason Peninsula since 1975 , observing that the ice shelf is sustained by snow accumulation as there is no significant glacier input from Jason Peninsula. For the majority of the Larsen $\mathrm{C}$ ice front, to Gipps Ice Rise, there was major change between 1975 and 1988. The ice shelf is heavily rifted and crevassed, strongly influenced by the inflow of land ice, mainly through Cabinet, Mill, Whirlwind and Mobiloil Inlets. A section broke off the northernmost part, shortly after being hit by an iceberg in 1976, but the major change occurred in 1986 by the calving of two giant icebergs. The larger berg was $\sim 6520 \mathrm{~km}^{2}$ in area and the smaller one $\sim 1260 \mathrm{~km}^{2}$ (Skvarca, 1994). In total the area of ice lost from Larsen C between 1975 and 1988 was $7800 \mathrm{~km}^{2}$. Since then there have been no further large calving events and the ice front has been slowly advancing. It is currently at $90 \%$ of its original size (in 1963) and appears to remain stable.

Prior to the calving event in 1986, the ice shelf floated free to the north of Gipps Ice Rise. The rise acted as a constraining point causing chasms and inlets to form parallel to the ice front, which formed lines of weakness where the calving took place (Skvarca, 1994). It is thought that this was not climate-driven retreat but part of the natural process of ice shelf mass balance regulation. If the same atmospheric and oceanic forces are at play which caused its neighbours to collapse, however, Larsen C Ice Shelf is also expected to retreat. The timescale and possible mechanism are as yet uncertain.

Using satellite radar measurements from 1992 and 2001, Shepherd et al. (2003) found that the northernmost sections of Larsen $\mathrm{C}$ displayed the greatest decrease in surface elevation, $0.27 \pm 0.11 \mathrm{ma}^{-1}$. Towards the southern tip however, the ice shelf thickened where ice is discharged from Palmer Land. The mean rate of elevation change of Larsen $\mathrm{C}$ was $0.08 \pm 0.04 \mathrm{ma}^{-1}$. There is evidence that nearby Weddell Deep Waters (WDW) have warmed (Robertson et al., 2002), and in 2002 oceanographic measurements showed large quantities of Modified Weddell Deep Waters (MWDW) present in front of the northern Larsen C (Nicholls et al., 2004). The study by Shepherd et al. (2003) stated that although basal melt rates are uncertain, enhanced ocean melting has been and is thinning the Larsen Ice Shelf. They predicted that if basal melting continues at the estimated rate of $0.78 \mathrm{ma}^{-1}$, Larsen $\mathrm{C}$ will approach the thickness of Larsen $\mathrm{B}$ at the time of its collapse in around 100 years, or more rapidly with a warming ocean (Shepherd et al., 2003).

Conversely, other research indicates that it is unlikely that temperature changes of the deep Weddell Sea are having a major impact on melt rates at the base of Larsen C Ice Shelf (Nicholls et al., 2004). Observations show that although MWDW is present at the ice front, the Ice Shelf Water is not derived from this directly, but from MWDW pre-conditioned by winter cooling and by salinification from sea-ice production. This suggests that there is no clear source of warm water for increased basal melting, since the pre-conditioned MWDW is cooled to the surface freezing 


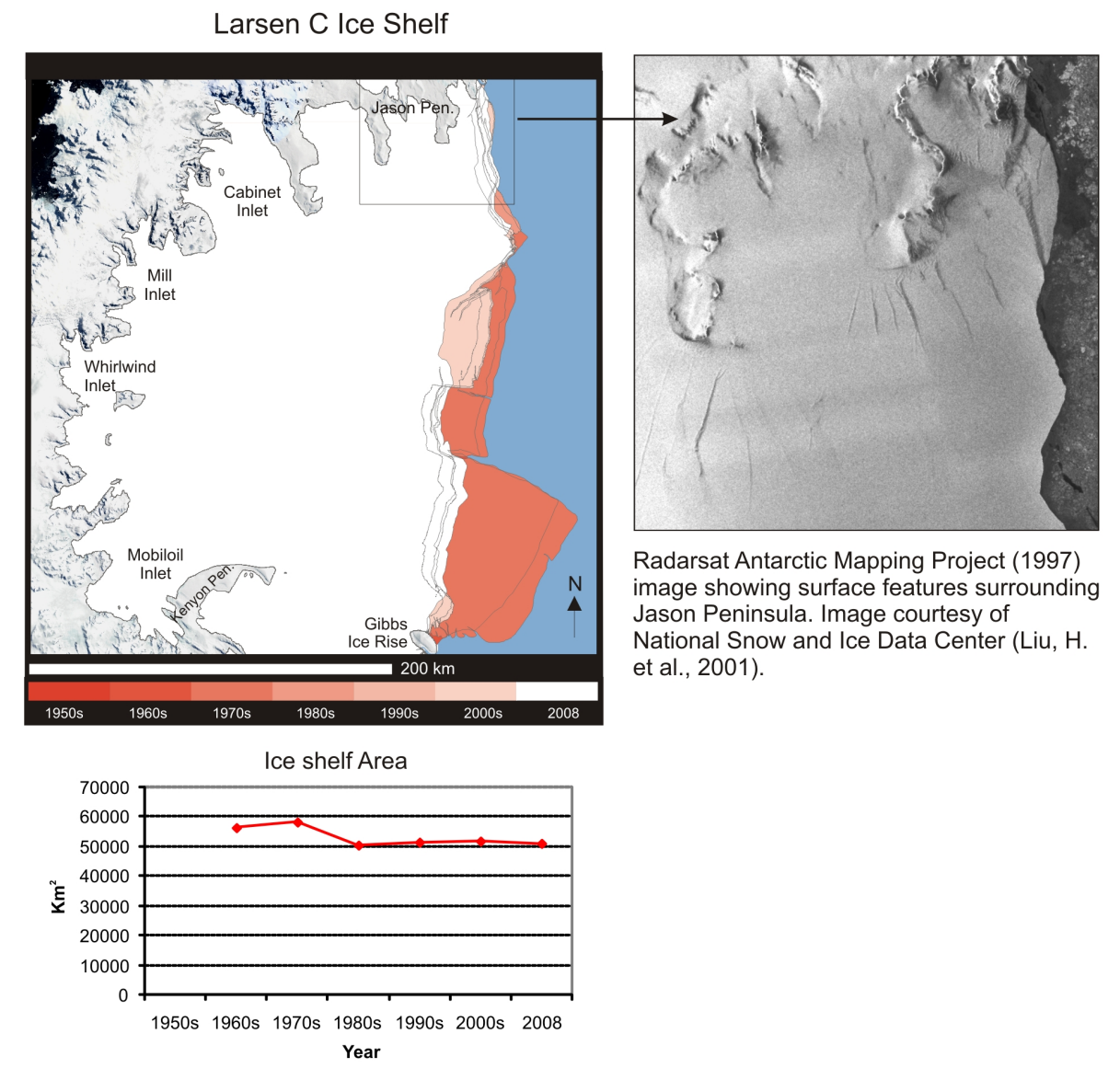

Fig. 4.11. Larsen C Ice Shelf

temperature. Recent modelling suggests there are regions of basal freezing (Holland et al., 2009) and this supports the prevalence of cold MWDW beneath Larsen Ice Shelf. There is an urgent need for more data before further conclusions can be drawn (Nicholls et al., 2004).

\subsubsection{Larsen D (Fig. 4.12)}

Larsen D Ice Shelf is a unique ice shelf on the AP, as it has advanced over the past 50 years, although this has been small relative to the retreats of the other ice shelves. The ice shelf extends from Gipps Ice Rise $\left(68^{\circ} 45^{\prime} \mathrm{S}, 60^{\circ} 45^{\prime} \mathrm{W}\right)$ southwards to Smith Peninsula $\left(74^{\circ} 30^{\prime} \mathrm{S}, 61^{\circ} \mathrm{W}\right)$. The first ice front position for this study was mapped from oblique aerial photographs taken in 1966 and the area calculated at $21700 \mathrm{~km}^{2}$. The most recent calculation was $22600 \mathrm{~km}^{2}$. Within that time there have been small fluctuations but it can be concluded that Larsen $\mathrm{D}$ is generally stable. This ice shelf is the furthest from the thermal limit of viability and so it appears unlikely that it will show signs of change until this limit is driven southwards. The Larsen D has been barely mentioned in reports of AP ice shelves. Skvarca (1994) observed ice margin changes between Gipps Ice Rise and Ewing Island and noted a steady advance between 1975 and 1988. In the same period, the surrounding area of fast-ice receded. Fastice exists along the whole front of the Larsen D Ice Shelf. It makes ice front interpretation difficult as the semi-permanent sea-ice is of varying thicknesses and almost indistinguishable from shelf ice on some satellite images. For this study, it was important to select a consistent ice front between images to accurately represent the real position for each decade. Although more difficult to interpret than other ice shelves, the results accurately describe the small variations that occurred in this area.

\section{Discussion}

Atmospheric warming on the Antarctic Peninsula over the past 50 years has been widely documented (King and Harangozo, 1998; King, 1994; Harangozo et al., 1994; Skvarca et al., 1998; Vaughan et al., 2003; Morris and Vaughan, 2003; Marshall et al., 2006). At a rate of $3.7 \pm 1.6^{\circ} \mathrm{C}{\text { (century })^{-1}}^{-1}$ this is significantly higher than the global mean $\left(0.6 \pm 0.2^{\circ} \mathrm{C}\right.$ during the 20th Century) and also the rest of the Antarctic continent (Vaughan et al., 2003). The ultimate cause of the atmospheric changes remains to be determined but there is emerging evidence that it can be linked to human 


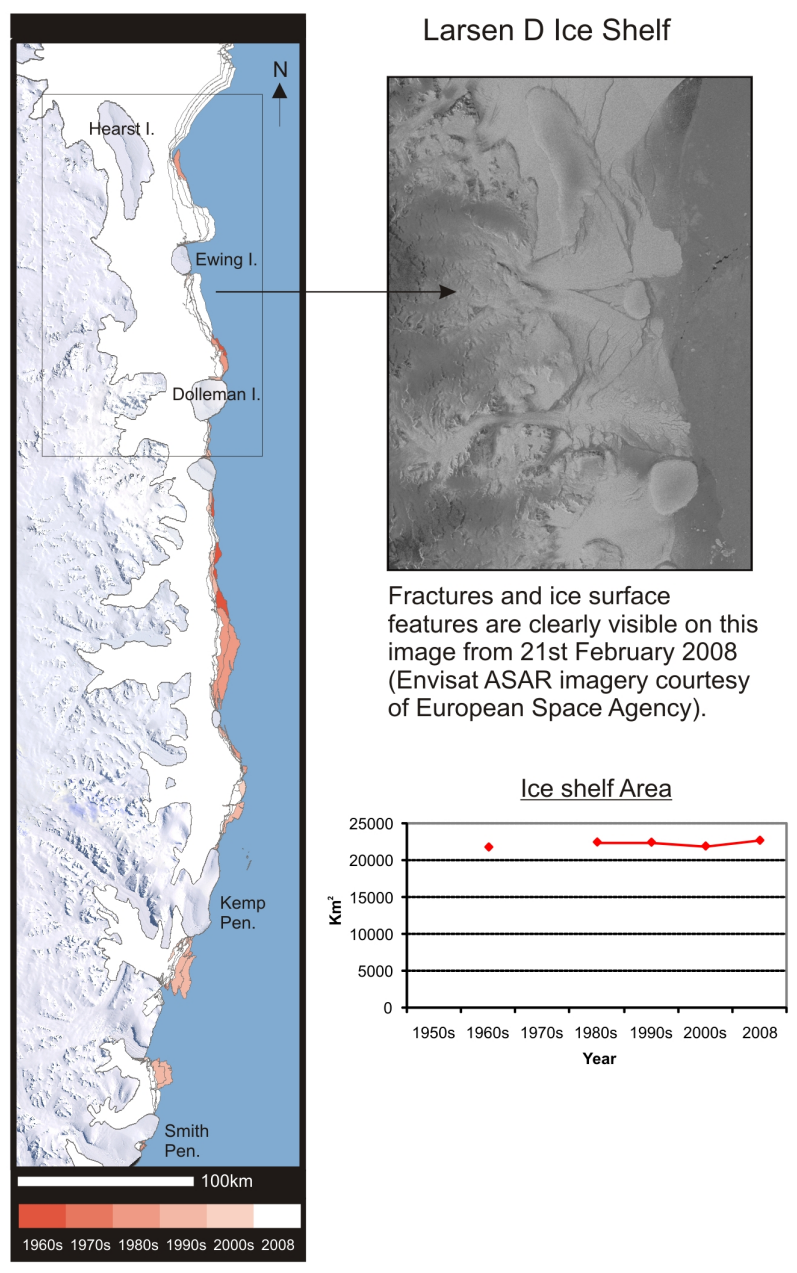

Fig. 4.12. Larsen D Ice Shelf

activity (Marshall et al., 2006). However, the key point in this warming, is perhaps, that while AP warming is strongest in the winter months, warming in the summer is also statistically significant and has been sufficient to cause a substantial increase in surface melt-water production on several ice shelves (Vaughan, 2006), and the pattern of this increased availability of melt-water appears to be linked with the pattern and sequence of ice-shelf retreat.

A map showing interpolated mean annual temperature across the AP shows a contrast $\left(3-5^{\circ} \mathrm{C}\right)$ between the east and west coast and also reveals that the limit of ice shelves closely follows the $-9^{\circ} \mathrm{C}$ isotherm (Morris and Vaughan, 2003) (see Fig. 1b). The limit of ice shelves that have retreated in the last 100 years is bounded by the $-9^{\circ} \mathrm{C}$ and $-5^{\circ} \mathrm{C}$ isotherms, suggesting that the retreat of ice shelves in the AP region is consistent with a warming of around $\sim 4^{\circ} \mathrm{C}$ (Morris and Vaughan, 2003). The retreat of ice shelves on the Antarctic Peninsula over the past century is now widely attributed to atmospheric warming (e.g., Vaughan and Doake, 1996; Doake and Vaughan, 1991a; Mercer, 1978; Rott et al., 1998; Skvarca et al., 1999).
One ice front does not appear to fit within the pattern of ice-shelf retreat being directly related to atmospheric warming. Prior to this study, fluctuations in the position of the southern ice front of George VI Ice Shelf have not been discussed in the literature. Although the ice shelf has changed little overall, the southern front has shown retreat since the 1950s and yet it lies south of the predicted limit of viability. Because few ice-front positions were available, this ice shelf was not included in earlier studies that sought to establish a connection between the known pattern of atmospheric temperatures with ice-shelf changes through discussion of a southerly-migrating "limit of viability" for ice shelves (Vaughan and Doake, 1996; Morris and Vaughan, 2003). The map presented by Morris and Vaughan was derived by a multivariate regression technique in which the mean residuals were approximately two degrees. It shows that the mean annual temperature in the area around the southern ice front of George VI Ice Shelf is $-10^{\circ} \mathrm{C}$ (Fig. 1b). This is slightly cooler than the $-9^{\circ} \mathrm{C}$ mean annual temperature that was identified as the limit of viability for ice shelves, which lies to the north. Certainly, this new information requires a reassessment, or at least adjustment, of the hypothesised $-9^{\circ} \mathrm{C}$ isotherm as the limit of viability. The gradient of isotherms is shallower on the west coast and therefore the isotherm locations could be less precise in this region. To investigate whether the concept of a thermal limit of viability of ice shelves can survive the introduction of this new data, we must either: determine the distribution of mean annual air temperature in greater detail; allow that the limit can only be identified in approximate terms (existing in the region of -9 to $-10^{\circ} \mathrm{C}$ ); or investigate whether a more refined description of the limit of viability is required. The concept of retreat being driven solely, and unambiguously, by the migration of a limit of viability based on atmospheric temperatures may be challenged by this increasing quality of data on ice-shelf retreat, so in future we must take into account other factors such as changes in ocean conditions, or refine the concept of the limit of viability based on air temperatures to include the number of Positive Degree Days (PDD).

Whether or not the strict concept of a limit of viability is proved simplistic, the general pattern of ice-shelf retreat still appears to show a connection increasing atmospheric temperature, and production of melt-water. But within this pattern, the specific behaviour of the ice shelves in their response to the warming climate has, as detailed above, varied considerably, from slow, steady retreat by calving to rapid disintegration. It appears that many processes are significant in modifying the style and rate of retreat. 
Ice-shelf dynamics and other forcing mechanisms have been suggested to explain particular phases of retreat and collapse. The geometry of the embayment in which an ice shelf sits, has been shown to have had an effect in controlling the response of different sides of an ice shelf within a channel (e.g. Jones Ice Shelf and Prince Gustav Ice Shelf). The geometry of the ice front itself could also promote disintegration: some ice front configurations may lead to a "compressive arch" that leads to stabilization of the ice front position, but if this arch is breached rapid retreat may follow; a mechanism that may have been significant on Larsen B Ice Shelf. The presence of pinning points can also affect the course of retreat. This was seen in the Wordie Ice Shelf, where major ice rises acted as wedges and contributed to weakening, hastening break-up. Conversely, pinning points appear also to have acted to support an ice shelf, as in the case of Jones Ice Shelf, where a small ice rise delayed the retreat of the western side.

Not only the stress regime, but also the mass balance regime strongly affects the behaviour of the ice shelf. Where shelf ice is not fed by grounded ice, it relies on in-situ accumulation and appears to be more susceptible to rapid breakup through surface melting and thinning (e.g. Wilkins Ice Shelf). The early suggestion that the presence of surface melt-water, or the changed temperature structure this might cause, could cause retreat by reducing the fracture toughness of the ice (Doake and Vaughan, 1991b), has rarely been mentioned since, but has not been fully discounted. Whereas, the role of melt-water in opening crevasses has been widely discussed and substantially developed. It is thus now well established that surface melt-water can be both an instigator and indicator of imminent ice-shelf collapse (e.g. Larsen A, Larsen B and Wilkins Ice Shelves), although in the case of George VI Ice Shelf, which is under uniaxial compression the ice shelf appears to have survived for many decades despite the presence of large melt ponds. Only the currently retreating ice shelves (Larsen B and Wilkins) and the northernmost portion of Larsen C Ice Shelf, have the firn characteristics and melt season length associated with imminent break-up (Scambos et al., 2003). The melting may be caused by atmospheric warming, but the mechanism for break-up is described as being a vertical propagation of water through crevasses causing initial fragmentation of the ice shelf (van der Veen, 2007; Scambos et al., 2008). A "domino effect" may also occur as the rifted ice blocks topple, causing mass disintegration (e.g. Larsen B Ice Shelf) (MacAyeal et al., 2003). The melt pools observed on the surface of the Larsen $\mathrm{C}$ Ice Shelf currently lie to the north of the position of the $-9^{\circ} \mathrm{C}$ isotherm and may be the precursor to collapse in this region, but without knowing the rate of southwards migration of the limit of viability the timescale is difficult to predict.

The surface texture, ice thickness and ice velocity also play an important part in determining the behaviour of an ice shelf undergoing retreat. It is also possible that rheological weakening of the shear margins can cause an increase in the ice flow rates (e.g., Larsen B), and the development of rifts and the rupturing of sutures between flow units can precondition an ice shelf to collapse (Glasser and Scambos, 2008).

Finally, there appears to be evidence of ice-shelf thinning caused by ocean-driven basal melting (Shepherd et al., 2003), which could pre-condition ice shelves to retreat. Indeed, there is an undoubted ocean influence on ice shelves; for example due to warm intrusions of Upper Circumpolar Deep Water currents (southern George VI ice front and Müller Ice Shelf) and Modified Weddell Deep Waters (Larsen B and Larsen C Ice Shelves). Furthermore, recent modelling has suggested that the basal melt of ice shelves would increase quadratically in response to ocean warming (Holland et al., 2008). However, there is as yet insufficient data to determine whether there are changes in Southern Ocean circulation sufficient to have contributed to retreat of AP ice shelves. Further oceanographic observations are needed to determine the extent to which ocean temperature and circulation change may impact on the ice shelves.

\section{Conclusions}

Ice-shelf retreat may be an icon of climate change science, but not all ice-shelf retreats are the same. There are a variety of responses: protracted retreat, rapid collapse and possibly staged-collapse. The rate of retreat does not simply appear to be related to the rate of change of climate, but it is modulated by the ice-shelf configuration and conditions of mass balance. It is not clear exactly which processes dominate in each case or why. There are speculations, but very little definitive interpretation because most ice shelves can be subject to several different forces. The foregoing discussion suggests that the theory of a thermal air temperature limit of viability seems to work in broad terms but may only be sufficient to explain or predict the general pattern of change. It is almost certainly insufficient to give a more precise predictive capacity for any individual ice shelf. The prediction by Vaughan et al. (1993) that Wilkins Ice Shelf would collapse in thirty years was arguably 50\% wrong, in that much of this ice shelf has already been lost. However, it is questionable whether that ad hoc prediction could be much improved today. The basis for prediction continues to be based on observing the broad patterns and expecting them to continue, rather than on fundamental understanding or improvements in modelling. The ice-shelf dynamics we have discussed above (including ice-shelf geometry, pinning points and pressure zones; surface melt and texture; mass balance, ice source, thickness and velocity) and external forces such as atmospheric and ocean temperature and sea-ice extent, impact the timing and style of collapse/retreat. We must undertake many more detailed modelling studies and careful sensitivity tests such as those undertaken by Vieli et al. (2007), before we can build an effective predictive model. Perhaps progress is not best 
served by over-focussing on a few examples when there are many to consider. This is especially important as a better understanding of ice-shelf retreat around the AP could also improve our modelling and projections of future changes in ice shelves around the West Antarctic Ice Sheet.

Acknowledgements. This study is part of the British Antarctic Survey programme Polar Science for Planet Earth. It was funded by The Natural Environment Research Council. We thank the US Geological Survey for providing the original funding that led to compilation of the coastal-change database and for access to the data for this research. We would also like to thank Doug Benn and an anonymous reviewer for their insightful and extremely thorough formal reviews, and Mauri Pelto, for the stimulating interactive comment on our paper, all of which led to a substantial improvement of our work.

Edited by: M. Van den Broeke

\section{References}

Braun, M. and Humbert, A.: Recent Retreat of Wilkins Ice Shelf Reveals New Insights in Ice Shelf Breakup Mechanisms, IEEE Geosci. Remote S., 6, 263-267, doi:10.1109/lgrs.2008.2011925, 2009.

Braun, M., Humbert, A., and Moll, A.: Changes of Wilkins Ice Shelf over the past 15 years and inferences on its stability, The Cryosphere, 3, 41-56, 2009, http://www.the-cryosphere-discuss.net/3/41/2009/.

Cook, A. J., Fox, A. J., Vaughan, D. G., and Ferrigno, J. G.: Retreating glacier fronts on the Antarctic Peninsula over the past halfcentury, Science, 308, 541-544, doi:10.1126/science.1104235, 2005.

Cooper, A. P. R.: Historical observations of Prince Gustav Ice Shelf, Polar Rec., 33, 285-294, 1997.

De Angelis, H. and Skvarca, P.: Glacier surge after ice shelf collapse, Science, 299, 1560-1562, 2003.

Doake, C. S. M.: State of balance of the ice sheet in the Antarctic Peninsula, Ann. Glaciol., 3, 77-82, 1982.

Doake, C. S. M. and Vaughan, D. G.: Breakup of Wordie Ice Shelf, Antarctica, Glacier-Ocean-Atmosphere Interactions, St Petersburg, 161-165, 1991a.

Doake, C. S. M. and Vaughan, D. G.: Rapid disintegration of Wordie Ice Shelf in response to atmospheric warming, Nature, 350, 328-330, 1991b.

Doake, C. S. M., Corr, H. F. J., Rott, H., Skvarca, P., and Young, N. W.: Breakup and conditions for stability of the northern Larsen Ice Shelf, Antarctica, Nature, 391, 778-780, 1998.

Domack, E. W., Ishman, S. E., Stein, A. B., McClennen, C. E., and Jull, A. J. T.: Late Holocene advance of Muller Ice Shelf, Antarctic Peninsula: sedimentological, geochemical and palaeontological evidence, Antarct. Sci., 7, 159-170, 1995.

Domack, E., Duran, D., Leventer, A., Ishman, S., Doane, S., McCallum, S., Amblas, D., Ring, J., Gilbert, R., and Prentice, M.: Stability of the Larsen B ice shelf on the Antarctic Peninsula during the Holocene epoch, Nature, 436, 681-685, 2005.

Ferrigno, J. G., Cook, A. J., Foley, K. M., Williams, R. S. J., Swithinbank, C., Fox, A. J., Thomson, J. W., and Sievers, J.: Coastal- change and glaciological map of the Trinity Peninsula area and South Shetland Islands, Antarctica: 1843-2001: U. S. Geological Survey Geologic Investigations Map Series Map I-2600-A, with 32 pp., pamphlet, 2006.

Ferrigno, J. G., Cook, A. J., Mathie, A. M., Williams, R. S. J., Swithinbank, C., Foley, K. M., Fox, A. J., Thomson, J. W., and Sievers, J.: Coastal-change and glaciological map of the Larsen Ice Shelf area, Antarctica: 1940-2005: U. S. Geological Survey Geologic Investigations Map Series Map I-2600-B, with 28 pp., pamphlet, 2008.

Fleming, W. L. S.: Relic glacial forms on the western seaboard of Graham Land, Geogr. J., XCVI, 93-101, 1940.

Fox, A. J. and Vaughan, D. G.: The retreat of Jones Ice Shelf, Antarctic Peninsula, J. Glaciol., 51, 555-560, 2005.

Francis, S. J.: Survey report including a general account of country traversed for second sledge journey, 5-28 August 1947, Unpublished report, Cambridge: British Antarctic Survey Archives ref. AD6/2D/1947/L2, 1947.

Glasser, N. F. and Scambos, T. A.: A structural glaciological analysis of the 2002 Larsen B ice-shelf collapse, J. Glaciol., 54, 3-16, 2008.

Harangozo, S., Colwell, S. R., and King, J. C.: Interannual and long term air temperature variability in the southern Antarctic Peninsula from a reconstructed record for eastern Alexander Island, 1994 ,

Holland, P. R., Jenkins, A., and Holland, D. M.: The response of ice shelf basal melting to variations in ocean temperature, J. Climate, 21, 2558-2572, doi:10.1175/2007jcli1909.1, 2008.

Holland, P. R., Corr, H. F. J., Vaughan, D. G., Jenkins, A., and Skvarca, P.: Marine ice in Larsen Ice Shelf, Geophys. Res. Lett., 36, L11604, doi:10.1029/2009g1038162, 2009.

Hulbe, C. L., Scambos, T. A., Youngberg, T., and Lamb, A. K.: Patterns of glacier response to disintegration of the Larsen B ice shelf, Antarctic Peninsula, Glob. Planet. Change, 63, 1-8, doi:10.1016/j.gloplacha.2008.04.001, 2008.

Humbert, A.: Numerical simulations of the ice flow dynamics of George VI Ice Shelf, Antarctica, J. Glaciol., 53(183), 659-664, 2007.

Humbert, A. and Braun, M.: The Wilkins Ice Shelf, Antarctica: break-up along failure zones, J. Glaciol., 54, 943-944, 2008.

Karstkarel, N.: Changes in Shelf Ice Extent in West Antarctica between 1840 and 1960: Analysing Historical Maps in a Geographic Information System, Circumpolar Studies 3, 1-170, 2005.

Khazendar, A., Rignot, E., and Larour, E.: Larsen B Ice Shelf rheology preceding its disintegration inferred by a control method, Geophys. Res. Lett., 34, L19503, doi:10.1029/2007GL030980, 2007.

King, J. C.: Recent climate variability in the vicinity of the Antarctic Peninsula, Int. J. Climatol., 14, 357-369, 1994.

King, J. C. and Harangozo, S. A.: Climate change in the western Antarctic Peninsula since 1945: observations and possible causes, Ann. Glaciol., 27, 571-575, 1998.

Liu, H., Jezek, K., Li, B., and Zhao, Z.: Radarsat Antarctic Mapping Project digital elevation model version 2. Boulder, Colorado USA: National Snow and Ice Data Center, Digital media, 2001.

Luchitta, B. K. and Rosanova, C. E.: Retreat of northern margins of George VI and Wilkins ice shelves, Antarctic Peninsula, Ann. Glaciol., 27, 41-46, 1998. 
MacAyeal, D. R., Scambos, T. A., Hulbe, C. L., and Fahnestock, M. A.: Catastrophic ice-shelf break-up by an ice-shelf-fragmentcapsize mechanism, J. Glaciol., 49, 22-36, 2003.

Marshall, G. J., Orr, A., van Lipzig, N. P. M., and King, J. C.: The Impact of a Changing Southern Hemisphere Annular Mode on Antarctic Peninsula Summer Temperatures, J. Climate, 19, 5388-5404, 2006.

Mercer, J. H.: West Antarctic ice sheet and $\mathrm{CO}_{2}$ greenhouse effect: a threat of disaster, Nature, 271, 321-325, 1978.

Morris, E. M. and Vaughan, D. G.: Spatial and temporal variation of surface temperature on the Antarctic Peninsula and the limit of viability of ice shelves, in: Antarctic Peninsula Climate Variability: Historical and Paleoenvironmental Perspectives. Antarctic Research Series, 79, edited by: Domack, E., Leventer, A., Burnett, A., Bindschadler, R., Convey, P., and Kirby, M., AGU, Washington, DC, 61-68, 2003.

Nicholls, K. W.: Predicted reduction in basal melt rates of an Antarctic ice shelf in a warmer climate, Nature, 388, 460-462, 1997.

Nicholls, K. W., Pudsey, C. J., and Morris, P.: Summertime water masses off the northern Larsen C Ice Shelf, Antarctica, Geophys. Res. Lett., 31, L09309, doi:10.1029/2004GL019924, 2004.

Payne, A. J., Vieli, A., Shepherd, A., Wingham, D. J., and Rignot, E.: Recent dramatic thinning of largest West Antarctic ice stream triggered by oceans, Geophys. Res. Lett., 31, L23401, doi:10.1029/1204GL021284, 2004.

Pearson, M. R. and Rose, I. H.: The dynamics of George VI Ice Shelf, Brit. Antarct. Surv. B., 52, 205-220, 1983.

Potter, J. R. and Paren, J. G.: Interaction between ice shelf and ocean in George VI Sound, Antarctica, Antar. Res. S., 43, 3557, 1985.

Pritchard, H. and Vaughan, D. G.: Widespread acceleration of tidewater glaciers on the Antarctic Peninsula, J. Geophys. Res., 112, F03S29, doi:10.1029/2006JF000597, 2007.

Pritchard, H. D., Arthern, R. J., Vaughan, D. G., and Edwards, L. A.: Extensive dynamic thinning on the margins of the Greenland and Antarctic ice sheets, Nature, 461, 971-975, doi:10.1038/nature08471, 2009.

Pudsey, C. J. and Evans, J.: First survey of Antarctic sub-ice shelf sediments reveals mid-Holocene ice shelf retreat, Geology, 29, 787-790, 2001.

Rack, W., Doake, C. S. M., Rott, H., Siegel, A., and Skvarca, P.: Interferometric analysis of the deformation pattern of the northern Larsen Ice Shelf, Antarctic Peninsula, compared to field measurements and numerical modeling, Ann. Glaciol., 31, 205-210, 2000.

Reece, A.: The ice of Crown Prince Gustav Channel,Graham Land, Antarctica, J. Glaciol., 1, 404-409, 1949.

Reynolds, J. M.: The structure of Wordie Ice Shelf, Antarctic Peninsula, Brit. Antarct. Surv. B., 80, 57-64, 1988.

Ridley, J. K.: Surface melting on Antarctic Ice Shelves detected by passive microwave sensors, Geophys. Res. Lett., 20, 2639-2642, 1993.

Rignot, E., Casassa, G., Gogineni, P., Krabill, W., Rivera, A., and Thomas, R.: Accelerated ice discharge from the Antarctic Peninsula following the collapse of Larsen B ice shelf, Geophys. Res. Lett., 31, L18401, doi:10.1029/2004GL020679, 2004.

Rignot, E., Casassa, G., Gogineni, S., Kanagaratnam, P., Krabill, W., Pritchard, H., Rivera, A., Thomas, R., and Vaughan, D.:
Recent ice loss from the Fleming and other glaciers, Wordie Bay, West Antarctic Peninsula, Geophys. Res. Lett., 32, L07502, doi:10.1029/2004GL021947, 2005.

Roberts, S. J., Hodgson, D. A., Bentley, M. J., Smith, J. A., Millar, I. L., Olive, V., and Sugden, D. E.: The Holocene history of George VI Ice Shelf, Antarctic Peninsula from clast-provenance analysis of epishelf lake sediments, Paleogeography, Palaeoclimatology, Palaeoecology, 259, 258-283, doi:10.1016/j.palaeo.2007.10.010, 2005.

Robertson, R., Visbeck, M., Gordon, A. L., and Fahrbach, E.: Longterm temperature trends in the deep waters of the Weddell Sea, Deep-Sea Res. Pt. II, 49, 4791-4806, 2002.

Rott, H., Skvarca, P., and Nagler, T.: Rapid collapse of Northern Larsen Ice Shelf, Antarctica, Science, 271, 788-792, 1996.

Rott, H., Rack, W., Nagler, T., and Skvarca, P.: Climatically induced retreat and collapse of northern Larsen Ice Shelf, Antarctic Peninsula, Ann. Glaciol., 27, 86-92, 1998.

Rott, H., Rack, W., Skvarca, P., and de Angelis, H.: Northern Larsen Ice Shelf, Antarctica: further retreat after collapse, Ann. Glaciol., 34, 277-282, 2002.

Scambos, T. A., Hulbe, C., Fahnestock, M., and Bohlander, J.: The link between climate warming and break-up of ice shelves in the Antarctic Peninsula, J. Glaciol., 46, 516-530, 2000.

Scambos, T., Hulbe, C., and Fahnestock, M.: Climate-induced ice shelf disintegration in the Antarctic Peninsula, in: Antarctic Peninsula Climate Variability: Historical and Paleoenvironmental Perspectives. Antarctic Research Series, 79, edited by: Domack, E., Leventer, A., Burnett, A., Bindschadler, R., Convey, P., and Kirby, M., AGU, Washington, DC, 79-92, 2003.

Scambos, T. A., Bohlander, J. A., Shuman, C. A., and Skvarca, P.: Glacier acceleration and thinning after ice shelf collapse in the Larsen B embayment, Antarctica, Geophys. Res. Lett., 31, L18402, doi:10.1029/2004GL020670, 2004.

Scambos, T., Ross, R., Bauer, R., Yermolin, Y., Skvarca, P., Long, D., Bohlander, J., and Haran, T.: Calving and ice-shelf break-up processes investigated by proxy: Antarctic tabular iceberg evolution during northward drift, J. Glaciol., 54, 579-591, 2008.

Scambos, T., Fricker, H. A., Liu, C. C., Bohlander, J., Fastook, J., Sargent, A., Massom, R., and Wu, A. M.: Ice shelf disintegration by plate bending and hydro-fracture: Satellite observations and model results of the 2008 Wilkins ice shelf break-ups, Earth Planet. Sci. Lett., 280, 51-60, doi:10.1016/j.epsl.2008.12.027, 2009.

Scientific Committee on Antarctic Research: The Antarctic digital database, Version-4.1, http://www.add.scar.org/, 2005.

Shepherd, A., Wingham, D., Payne, T., and Skvarca, P.: Larsen ice shelf has progressively thinned, Science, 302, 856-859, 2003.

Skvarca, P.: Fast recession of the Northern Larsen Ice Shelf monitored by space images, Ann. Glaciol., 17, 317-321, 1993.

Skvarca, P.: Change and surface features of the Larsen Ice Shelf, Antarctica, derived from Landsat and Kosmos mosaics, Ann. Glaciol., 20, 6-12, 1994.

Skvarca, P., Rack, W., Rott, H., and Donangelo, T. I. Y.: Evidence of recent climatic warming on the eastern Antarctic Peninsula, in: Ann. Glaciol., 27, 628-632, 1998.

Skvarca, P., Rack, W., Rott, H., and Donangelo, T. I. Y.: Climatic trend and the retreat and disintegration of ice shelves on the Antarctic Peninsula: an overview, Polar Res., 18, 151-157, 1999. 
Skvarca, P., De Angelis, H., and Zakrajsek, A. F.: Climatic conditions, mass balance and dynamics of Larsen B ice shelf, Antarctic Peninsula, prior to collapse, 7th International Symposium on Antarctic Glaciology (ISAG-7), Milan, ITALY, ISI:000232368400083, 557-562, 2003.

Smith, J. A., Bentley, M. J., Hodgson, D. A., and Cook, A. J.: George VI Ice Shelf: past history, present behaviour and potential mechanisms for future collapse, Antarct. Sci., 19, 131-142, doi:10.1017/s0954102007000193, 2007.

Suyetova, I. A.: The area of Antarctica and its ice shelves (on the basis of new cartographic data), Polar Geography, 10, 213-226, 1986.

Swithinbank, C. W. M. and Luchitta, B. K.: Multispectral digital image mapping of Antarctic ice features, Ann. Glaciol., 8, 159163, 1986.

van den Broeke, M.: Strong surface melting preceded collapse of Antarctic Peninsula ice shelf, Geophys. Res. Lett., 32, L12815, doi:10.1029/2005GL0223247, 2005.

van der Veen, C. J.: Fracture propagation as means of rapidly transferring surface meltwater to the base of glaciers, Geophys. Res. Lett., 34(5), L0150110, doi:1029/2006g1028385, 2007.

Vaughan, D. G.: Implications of the break-up of Wordie Ice Shelf, Antarctica for sea level, Ant. Sci., 5(4), 403-408, 1993.

Vaughan, D. G., Mantripp, D. R., Sievers, J., and Doake, C. S. M.: A synthesis of remote sensing data on Wilkins Ice Shelf, Antarctica, Ann. Glaciol., 17, 211-218, 1993.

Vaughan, D. G. and Doake, C. S. M.: Recent atmospheric warming and retreat of ice shelves on the Antarctic Peninsula, Nature, 379, 328-331, 1996.
Vaughan, D. G., Marshall, G. J., Connolley, W. M., King, J. C., and Mulvaney, R.: Climate Change: Devil in the Detail, Science, 293, 1777-1779, 2001.

Vaughan, D. G., Marshall, G. J., Connolley, W. M., Parkinson, C. L., Mulvaney, R., Hodgson, D. A., King, J. C., Pudsey, C. J., and Turner, J.: Recent rapid regional climate warming on the Antarctic Peninsula, Climatic Change, 60, 243-274, 2003.

Vaughan, D. G.: Recent trends in melting conditions on the Antarctic Peninsula and their implications for ice-sheet mass balance, Arctic, Antarctic and Alpine Research, 38, 147-152, 2006.

Vieli, A., Payne, A. J., Du, Z. J., and Shepherd, A.: Numerical modelling and data assimilation of the Larsen B ice shelf, Antarctic Peninsula, Philos. T. R. Soc. A., 364, 1815-1839, 2006.

Vieli, A., Payne, A. J., Shepherd, A., and Du, Z.: Causes of precollapse changes of the Larsen B ice shelf: Numerical modelling and assimilation of satellite observations, Earth Planet. Sc. Lett., 259, 297-306, doi:10.1016/j.epsl.2007.04.050, 2007.

Wager, A. C.: Flooding of the ice shelf in George VI Sound, Brit. Antarct. Surv. B., 28, 71-74, 1972.

Walker, D. P., Brandon, M. A., Jenkins, A., Allen, J. T., Dowdeswell, J. A., and Evans, J.: Oceanic heat transport onto the Amundsen Sea shelf through a submarine glacial trough, Geophys. Res. Lett., 34(4), L0260210, doi:1029/2006g1028154, 2007.

Ward, C. G.: The mapping of ice front changes on Muller Ice Shelf, Antarctic Peninsula, Antarct. Sci., 7, 197-198, 1995.

Williams, R. S. J. and Ferrigno, J. G.: U.S. Geological Survey Fact Sheet 50-98, 1998. 